\title{
RNAs and RNA-Binding Proteins in Immuno-Metabolic Homeostasis and Diseases
}

\author{
Esam S. B. Salem ${ }^{1,2 t}$, Andrew D. Vonberg ${ }^{1+}$, Vishnupriya J. Borra ${ }^{1}$, Rupinder K. Gill ${ }^{1}$ and \\ Takahisa Nakamura ${ }^{1,3,4,5 *}$ \\ ${ }^{1}$ Division of Endocrinology, Cincinnati Children's Hospital Medical Center, Cincinnati, OH, United States, ${ }^{2}$ Department of \\ Pharmacology and Systems Physiology, University of Cincinnati College of Medicine, Cincinnati, OH, United States, ${ }^{3}$ Division \\ of Developmental Biology, Cincinnati Children's Hospital Medical Center, Cincinnati, OH, United States, ${ }^{4}$ Department of \\ Pediatrics, University of Cincinnati College of Medicine, Cincinnati, $\mathrm{OH}$, United States, ${ }^{5}$ Department of Metabolic \\ Bioregulation, Institute of Development, Aging and Cancer, Tohoku University, Sendai, Japan
}

OPEN ACCESS

Edited by:

Ippei Shimizu,

Niigata University, Japan

Reviewed by:

Seitaro Nomura,

The University of Tokyo, Japan

Jaetaek Kim,

Chung-Ang University, South Korea

*Correspondence:

Takahisa Nakamura

takahisa.nakamura@cchmc.org

${ }^{\dagger}$ Co-first authors

Specialty section:

This article was submitted to

Cardiovascular Metabolism,

a section of the journal

Frontiers in Cardiovascular Medicine

Received: 04 June 2019

Accepted: 17 July 2019

Published: 20 August 2019

Citation:

Salem ESB, Vonberg AD, Borra VJ, Gill RK and Nakamura T (2019) RNAs

and RNA-Binding Proteins in

Immuno-Metabolic Homeostasis and Diseases.

Front. Cardiovasc. Med. 6:106 doi: 10.3389/fcvm.2019.00106
The increasing prevalence of worldwide obesity has emerged as a major risk factor for type 2 diabetes (T2D), hepatosteatosis, and cardiovascular disease. Accumulating evidence indicates that obesity has strong inflammatory underpinnings tightly linked to the development of metabolic diseases. However, the molecular mechanisms by which obesity induces aberrant inflammation associated with metabolic diseases are not yet clearly defined. Recently, RNAs have emerged as important regulators of stress responses and metabolism. RNAs are subject to changes in modification status, higher-order structure, and cellular localization; all of which could affect the affinity for RNA-binding proteins (RBPs) and thereby modify the RNA-RBP networks. Proper regulation and management of RNA characteristics are fundamental to cellular and organismal homeostasis, as well as paramount to health. Identification of multiple single nucleotide polymorphisms (SNPs) within loci of fat mass- and obesity-associated protein (FTO) gene, an RNA demethylase, through genome-wide association studies (GWAS) of T2D, and functional assessments of FTO in mice, support the concept that disruption in RNA modifications leads to the development of human diseases including obesity and metabolic disorder. In obesity, dynamic alterations in modification and localization of RNAs appear to modulate the RNA-RBP networks and activate proinflammatory RBPs, such as double-stranded RNA (dsRNA)-dependent protein kinase (PKR), Toll-like receptor (TLR) 3 and TLR7, and RNA silencing machinery. These changes induce aberrant inflammation and the development of metabolic diseases. This review will describe the current understanding of the underlying causes of these common and altered characteristics of RNA-RBP networks which will pave the way for developing novel approaches to tackle the pandemic issue of obesity.

Keywords: obesity, RNA methylation, PKR, snoRNA, CCR4-NOT complex, RNA silencing, Ago2, TRBP 


\section{INTRODUCTION}

In the past several decades, dramatic and rapid changes in lifestyle and dietary trends have led to obesity becoming a worldwide problem, bringing with it a host of chronic metabolic diseases, including type 2 diabetes (T2D), nonalcoholic steatohepatitis (NASH), non-alcoholic fatty liver disease (NAFLD), and cardiovascular disease (CVD). The global prevalence has reached epidemic proportions. In 2015, 603.7 million adults and 107.7 million children were considered obese, and yet these figures are predicted to continue to increase worldwide (1). Despite the enormous burden on global public health, effective preventive and/or therapeutic strategies are limited, as mechanisms underlying this cluster of pathologies remain unclear.

In 2007, two independent genome-wide association studies (GWAS) evaluating patients with T2D revealed fat mass- and obesity-associated protein (FTO) as the first GWAS-identified diabetes susceptibility locus $(2,3)$. Initial reports suggested multiple single nucleotide polymorphisms (SNPs) within the first intron of FTO found on chromosome 16 were significantly associated with obesity in humans (4), although the association between FTO SNPs and FTO expression has been controversial (5-8). Clarity was provided in mouse model studies in which it was demonstrated that FTO plays a vitally important role in the regulation of fat mass, adipogenesis, and body weight (9). Importantly, FTO is the first N6-methyladenosine (m6A) demethylase of eukaryotic messenger RNA (mRNA) $(10,11)$, and the regulation of adipogenesis is associated with demethylase activity of FTO $(12,13)$. Subsequently, reports indicate that FTO demethylates not only m6A, but also $\mathrm{N} 6,2^{\prime}-\mathrm{O}$ dimethyladenosine $(\mathrm{m} 6 \mathrm{Am}), \mathrm{N} 1$-methyladenosine $(\mathrm{m} 1 \mathrm{~A})$, and regulate RNA stability $(14,15)$, with findings that further support the concept of RNA modification's role in the pathogenesis of obesity.

The biological significance of RNA modification remains largely unknown in metabolic disorders, yet accumulated evidence suggests that the dynamic regulation of RNA modifications could have profound impacts on mRNA splicing, translation, maturation of non-coding microRNAs (miRNAs), and interactions with RNA-binding proteins $(16,17)$. Recent findings, however, indicate that disruption of RNA homeostasis is often associated with cellular and metabolically-driven stresses that trigger inflammatory responses $(18,19)$. In obesity, a wide range of inflammatory and stress conditions are often generated in liver and/or adipose tissue, among other insulintargeted tissues. These Inflammatory responses occur, at least in part, through activation of inflammatory RNA-binding proteins (RBPs), which includes double-stranded RNA (dsRNA)dependent protein kinase (PKR) (20), Toll-like receptor (TLR) 3 and TLR7 (21-23). These responses result in chronic, low grade, local inflammation capable of disrupting systemic metabolic homeostasis $(19,24,25)$. In addition, functional alterations of RBPs involved in RNA metabolism are associated with disruption in cellular energy homeostasis $(26,27)$. Therefore, altered RNA networks associated with RNA modification as a consequence of obesity may be a crucial step causing the inflammatory signaling cascades and abnormal RNA metabolism that lead to metabolic disorders. This review will summarize the advances and discoveries in the field of RNA modifications and RBPs, and discuss their contributions toward the pathogenesis of obesity and associated sequelae.

\section{Discovery of Fat Mass- and Obesity-Associated Gene, FTO}

The GWAS studies identified strong signals within intron 1 of the FTO gene associated with an increase in T2D, body mass index (BMI), and obesity (Table 1). Approximately 16\% of subjects homozygous for the risk allele of FTO weighed at minimum $3 \mathrm{~kg}$ more than subjects lacking the allele (54), with a $31 \%$ increased risk of developing obesity as compared to those subjects containing the non-risk allele (29). Two independent analyses in French and Sardinian studies confirmed a significant association of SNPs in the first intron of the FTO gene with increased BMI in individuals of European origin $(4,5)$. Moreover, these studies identified three additional SNPs within intron 1 of the FTO gene that were associated with severe childhood and morbid adult obesity (rs1421085 and rs17817449) $(4,5)$, and with obesity-related traits (rs9930506) (45), thus yielding a population attributable risk of $22 \%$ for common obesity (55). Subsequent studies reported that polymorphisms in the FTO genetic locus are also associated with onset and development of insulin resistance, metabolic syndrome, atherosclerosis, systemic hypertension, and alteration in C-reactive protein levels (Table 1) (56-60). The effects vary among different ethnic populations, thereby correlating the higher susceptibility of certain ethnicities to obesity with other modifying factors (61).

In a study investigating the link between the obesityassociated FTO SNPs and FTO expression, expression quantitative trait locus (eQTL) analysis failed to demonstrate that SNPs affected FTO expression in human tissues $(6,62,63)$. Charting the cis-regulatory circuitry within the FTO locus by the circular chromosome conformation capture (4C) method revealed that the locus physically interacts with the promoter sequence required for expression of Iroquois homeobox protein 3 (IRX3), which plays an early role during neural development, located approximately 500 kilobases (kb) away (64). In the human brain, obesity-associated FTO SNPs correlated with higher expression of IRX3, but not FTO, indicating that increased expression of IRX3 may be due to the genetic variation within FTO being responsible for the obesity-associated phenotypes. Consistently, IRX3-deficient mice are leaner and do not develop obesity after being place on a high fat diet, and hypothalamus-specific dominant-negative IRX3 mice also present with the same phenotype as IRX3-deficient mice (64). An independent study also reported that a FTO SNP, rs1421085, disrupts a conserved motif of the regulatory gene AT-rich interaction domain 5B (ARID5B), causing induction of IRX3 and IRX5 expression levels (65). This disruption leads to an autonomous developmental shift from beige energy-producing to white energy-storing adipocytes, which can explain the obesity-associated phenotypes observed in FTO risk variant(s).

These findings suggest the obesity and obesity-associated phenotypes observed in individuals who have FTO SNPs in intron 1 may be attributed to their potential to influence 
TABLE 1 | SNPs in FTO locus.

\begin{tabular}{|c|c|c|c|c|c|}
\hline FTO SNPS & Phenotype observed & $\begin{array}{l}\text { Region or country of } \\
\text { population studied }\end{array}$ & $\begin{array}{l}\text { Number } \\
\text { of studies }\end{array}$ & $\begin{array}{l}\text { Total enrollment across } \\
\text { all studies, ( } n=\text { subjects } \\
\quad+\text { healthy controls) }\end{array}$ & References \\
\hline $\begin{array}{l}\text { rs9939609 } \\
\text { (Intron 1) }\end{array}$ & $\begin{array}{l}\text { Correlations with increased BMI, } \\
\text { obesity, and in a few divergent } \\
\text { studies increased risk for } \\
\text { metabolic diseases (ex: T2D or } \\
\text { insulin sensitivity), though a few } \\
\text { studies reported no direct } \\
\text { correlation for T2D. Some } \\
\text { studies also showed that diet or } \\
\text { exercise can attenuate some of } \\
\text { the effects or heightened risk of } \\
\text { SNP presence }\end{array}$ & $\begin{array}{l}\text { Denmark, Finland, Europe, } \\
\text { Germany, Brazil, Spain, } \\
\text { United States, Japan, } \\
\text { Netherlands, South Asia, } \\
\text { Asia, Africa, China, Portugal }\end{array}$ & 18 & 518,014 & $(28-44)$ \\
\hline $\begin{array}{l}\text { rs9930506 } \\
\text { (Intron 1) }\end{array}$ & $\begin{array}{l}\text { Correlation with BMI, hip } \\
\text { circumference and total body } \\
\text { weight in Sardinian patients and } \\
\text { validated using 3,467 GenNet } \\
\text { samples }\end{array}$ & Sardinia & 1 & 6,148 & $(45)$ \\
\hline $\begin{array}{l}\text { rs8050136 } \\
\text { (Intron 1) }\end{array}$ & $\begin{array}{l}\text { Correlation with BMl and obesity, } \\
\text { but not with insulin sensitivity, } \\
\text { and second study found FTO } \\
\text { SNP does not affect weight loss } \\
\text { post-pregnancy }\end{array}$ & Germany and United States & 2 & 1,700 & $(46,47)$ \\
\hline $\begin{array}{l}\text { rs17818902 } \\
\text { (Intron 1) }\end{array}$ & $\begin{array}{l}\text { No direct correlation between } \\
\text { BMl or obesity to specific SNP }\end{array}$ & Czech Republic & 1 & 107 & $(48)$ \\
\hline $\begin{array}{l}\text { rs17817449 } \\
\text { (Intron 1) }\end{array}$ & $\begin{array}{l}\text { SNP correlates with } 22 \% \\
\text { increased risk of obesity in adults } \\
\text { and children }\end{array}$ & Europe & 1 & 8,000 & (5) \\
\hline $\begin{array}{l}\text { rs1558902 } \\
\text { (Intron 1) }\end{array}$ & $\begin{array}{l}\text { SNP does not affect weight loss } \\
\text { following obesity }\end{array}$ & United States & 1 & 742 & (49) \\
\hline $\begin{array}{l}\text { rs1421085 } \\
\text { (Intron 1) }\end{array}$ & $\begin{array}{l}\text { Increased risk for obesity and/or } \\
\text { T2D with SNP presence, but } \\
\text { physical activity can attenuate } \\
\text { effects }\end{array}$ & Europe and Global & 2 & 22,585 & $(50,51)$ \\
\hline $\begin{array}{l}\text { rs1121980 } \\
\text { (Intron 1) }\end{array}$ & $\begin{array}{l}\text { Increased risk for obesity and } \\
\text { higher BMI with SNP presence, } \\
\text { but physical activity can } \\
\text { attenuate effects }\end{array}$ & Europe & 2 & 131,795 & $(52,53)$ \\
\hline
\end{tabular}

The association between SNPs of fat mass- and obesity-associated (FTO) gene resulting in an impact on the development of obesity-associated phenotypes in multi-ethnic populations in different countries.

expression of IRX3 and IRX5, instead of FTO itself $(66,67)$. Nonetheless, animal models investigating FTO gene functions have clearly shown that FTO regulates energy metabolism, body weight, and adipogenesis (68). FTO-deficient mice exhibit significant reductions in fat and lean body mass due to greater energy expenditure and over-activation of the sympathetic system, suggesting the involvement of FTO in the regulation of energy homeostasis (69). Conversely, transgenic mice carrying extra copies of FTO intake significantly more food with greater weight gain, enhanced fat accumulation in adipose tissues, and impairment of glucose tolerance in a copy number-dependent manner (70). These metabolic phenotypes are consistent with the expression pattern of FTO mRNA abundant within cerebral tissues, including the hypothalamic centers, and points to FTO possibly controlling appetite and energy balance (71-73), although mice with FTO depletion within the hypothalamus presented with only a slight reduction in their body weight as compared to controls (72). Overall, these series of findings suggest that FTO plays a critical role regulating body weight and metabolism.

\section{The Role of FTO in RNA Demethylation}

FTO contains within its sequence a $\mathrm{Fe}^{2+}$ binding motif and a 2-oxyglutarate (2OG)-dependent oxygenase (71). Structurally, FTO protein is closely related to the bacterial DNA demethylase Alpha-ketoglutarate-dependent dioxygenase $(\mathrm{AlkB})$ and the mammalian AlkB homologs $\mathrm{ABH} 1$ and $\mathrm{ABH} 2$, which act on nucleic acids such as DNA and transfer RNA (tRNA) (74-77). A subsequent study identified FTO as the N6-methyladenosine $\left(\mathrm{m}^{6} \mathrm{~A}\right)$ demethylase of mRNA (Figure 1) (78). In mammals, adenosine methylation can directly be reversed by at least two demethylases, FTO and AlkB homolog 5 (ALKBH5) (79), while methyltransferase like 3 and 14 (METTL3,14) are enzymes that mediate the catalytic conversion of adenosine to m6A (80, 81). Recently, m6A has been found to play important roles in inflammation and antiviral responses (82). Genome-wide 
A

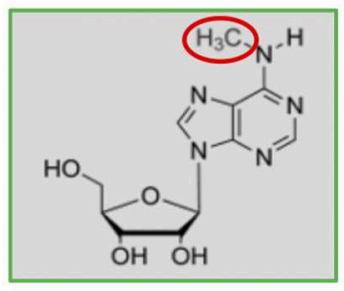

$\mathrm{N}^{6}$-methyladenosine $\left(m^{6} A\right)$

C

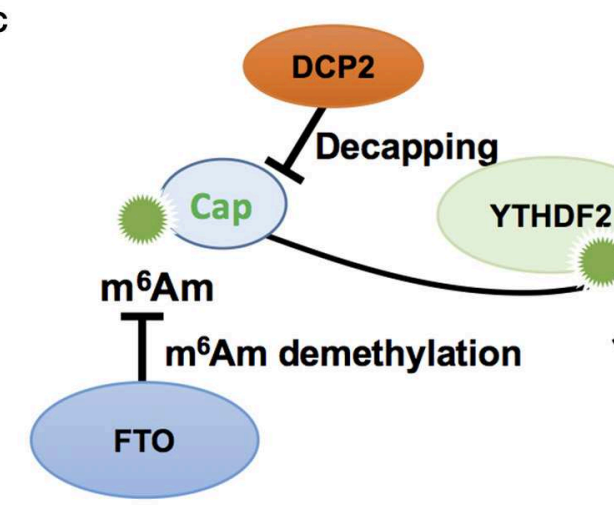

B

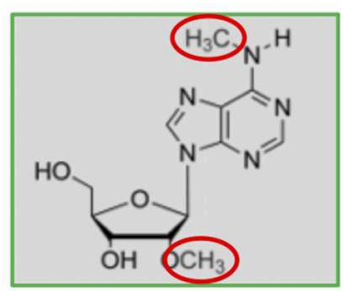

N6-methyl-2'-O-methyladenosine (m6 Am)

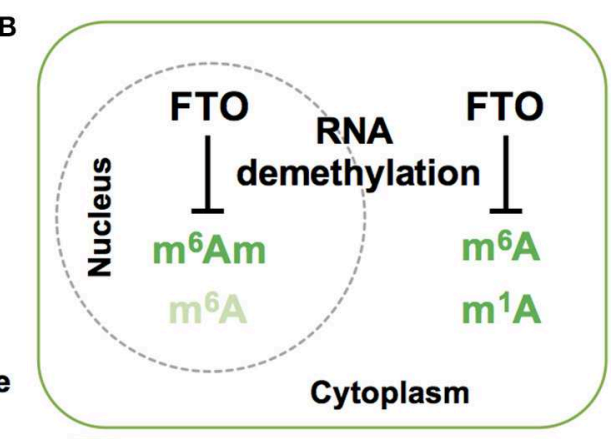

METTL16

RBM15

RBM15

ZFP217

m6A methylation

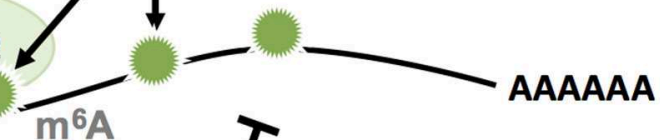

$\mathrm{m}^{6} \mathrm{~A}$

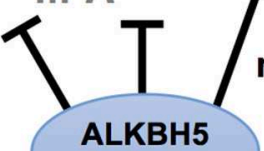

m6A demethylation

RNA methylation regulates:

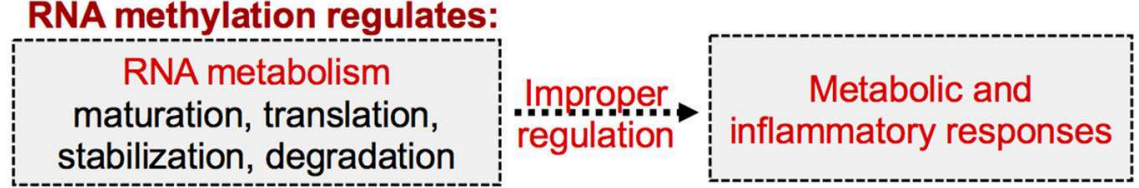

FIGURE 1 | Schematic representation of mRNA methylation modification in eukaryotic cells. (A) RNA methylation in adenosine often occurs, and has been previously reported, by attacking nitrogen and oxygen atoms as indicated in red circles of the following two described nucleotides: $m^{6} A$ and $m^{6} A m$. (B) Cellular localization of FTO, $m^{6} A, m^{6} A m$, and $m^{1} A$. FTO, first described as a nuclear protein, was later found to exist in both the cell nucleus and cytoplasm when observed in different mammalian cell lines. (C) RNA $m^{6} A$ and $m^{6} A m$ methylation and demethylation on mRNA. The mRNA methylation status affects mRNA metabolism and its improper regulation could result in abnormal metabolic and inflammatory responses.

transcriptome profiling following depletion of ALKBH5 was able to identify differentially expressed genes that regulate the immune response to viral infections, with METTL14 specific depletion altering pathways important in controlling metabolic reprogramming, stress responses, and aging (83). Furthermore, depletion of METTL3 and METTL14 has also been shown to lead to elevated levels of type I interferon responses to myriad viral infections $(83,84)$.

Of note, a recent study identified a novel role of FTO for RNA modification of the first encoded nucleotide next to the 7-methylguanosine cap, N6,2-prime-O-dimethyladenosine (m6Am), in controlling mRNA stability (Figure 1). This RNA modification is the preferred substrate of FTO, rather than m6A $(15,85)$, and selective demethylation of m6Am through FTO appears to destabilize mRNA (86). Analysis of m6Am transcriptomes revealed that its transcripts are more stable when compared to mRNAs starting from different nucleotides. The enhanced stability of m6Am-initiated transcripts appears to correlate with resistance by these transcripts to DCP2, an
mRNA-capping enzyme. A more recent study confirmed that FTO could effectively demethylate both m6A and cap m6Am and identified additional RNA substrates of FTO, including m1A in tRNA, m6A in U6 RNA, and internal and cap m6Am in small nuclear RNAs (snRNAs) (14). While FTO-mediated demethylation of internal $\mathrm{m} 6 \mathrm{~A}$ is compellingly associated with a plethora of biological processes, including, but not limited to, adipogenesis and inflammatory responses $(11,12,71,87)$, more comprehensive investigation of FTO-mediated demethylation action on other RNA species in response to environmental cues may provide deeper insights into cellular energy metabolism. For instance, RNA methylation-mediated regulation of mRNA stability could affect the efficiency of protein translation that accounts for a majority of cellular energy expenditure $(27,88)$.

Beyond simply the importance of FTO-mediated RNA methylation lies the presence of effective RBPs capable of recognizing and binding these methylated RNAs. One such RBP, YTH N6-Methyladenosine RNA Binding Protein 2 (YTHDF2), is an RNA-binding protein that belongs to the YTH 
domain-containing family. It regulates decay, destabilization, and degradation of methylated genes by selectively binding to previously described m6A-methylated mRNA within the $\mathrm{G}(\mathrm{m} 6 \mathrm{~A}) \mathrm{CU} / \mathrm{A}$ consensus, or by recruiting CCR4-NOT deadenylase complex (see the CCR4-NOT section below) within P-bodies found in the cytoplasm (89-92). YTHDF2 is implicated as having crucial roles in metabolic and inflammatory processes via modulation of expression levels of targeted and methylated mRNA transcripts. For example, FTO depletion inhibits adipogenesis by prolonging the cell cycle during adipocyte differentiation via decreased expression of methylated cyclin A2 (CCNA2) and cyclin-dependent kinase 2 (CDK2). This occurs through the action of $\mathrm{m} 6 \mathrm{~A}$ reader YTHDF2, thereby indicating the important role of YTHDF2 in FTO-mediated adipogenic control (93). In addition, depletion of YTHDF2 significantly enhanced the stimulation of multiple inflammatory signaling pathways such as of NF- $\mathrm{B}$ and mitogen-activated protein kinases (MAPKs), and elevated the expression levels of inflammatory cytokines such as TNF- $\alpha$ and IL6 (94). The consensus from these studies points to the role of $\mathrm{m} 6 \mathrm{~A}$ and its binding proteins in the regulation of immune-metabolic homeostasis and disorders such as obesity.

Technical advances have enhanced our ability to define the distribution profile and dynamic properties of m6A methylation by using sensitive and specific approaches. While chemical and antibody-based approaches have been developed and provided us important findings, there appear to be some limitations in these approaches. For instance, methylated RNA immunoprecipitation with anti-methylated RNA-specific antibodies and sequencing (MeRIP-seq) has been used to detect global m6A levels within 100 nucleotides length $(95,96)$. However, these approaches make identification and quantification of specific m6A methylation levels highly variable due to relatively poor sensitivity and weak specificity at single-nucleotide resolutions $(97,98)$. Furthermore, these antibody-based techniques make quantifying m6A stoichiometry difficult, especially when evaluating the deposition and level of m6A methylation fraction of modified transcripts (98-102). To overcome these difficulties, a recent study has developed a new antibody-independent method, the M6A-SensiTivE RNA digestion and sequencing (MASTERseq) (103), which is based on the ability of the MazF RNA endonuclease to cleave RNA specifically at unmethylated sites within "ACA" motifs (104). The MASTER-seq enables the detection and quantification of $\mathrm{m} 6 \mathrm{~A}$ at the single-base resolution at about $16-25 \%$ of all methylation sites. This study indicates that MASTER-seq could be used as a novel resource to quantify m6A levels in systemic scales of different cell types and compartments, as well as in varying pathologic conditions such as obesity (103).

\section{Molecular Pathways Sensing Ribose 2'-O-Methylation in Innate Immunity and Metabolism}

While m6A and m6Am appear to highly be associated with metabolic and inflammatory regulation, there are more than 100 different modes of RNA modifications, some of which are also involved in the innate immune defense mechanism in host cells $(105,106)$. Ribose $2^{\prime}$-O-methylation (2'-O-methylation) is one such RNA modification. In eukaryotes, mRNAs usually carry a $5^{\prime}$-cap structure that is methylated on the first and oftentimes the second cap-proximal nucleotides (N1 and N2, where $\mathrm{N}$ corresponds to any nucleotide), resulting in Cap1(m7GpppNmN) or Cap2- (m7GpppNmNm) mRNA. These methylations serve as a molecular signature of "self" to escape detection by innate immunity, and therefore mRNAs that do not contain any $2^{\prime}-O$-methylation close to the cap are marked as "non-self" and trigger the release of type I IFNs. Cap-specific mRNA (nucleoside-2'-O-)-methyltransferase 1 (CMTR1) dictates mRNA cap1 2'-O-ribose methylation of the mRNA 5'-cap structure. Importantly, dysregulation in CMTR1 expression is associated with several pathologies related to self-recognition immune mechanism from non-self RNAs. Consistently, it has been shown that uncapped viral RNAs can trigger an interferon-mediated antiviral response from the host. Mechanistically, several pro-inflammatory RBPs, including RIGI and MDA5, are potent regulators that bind and discriminate between "self" and "non-self" RNA (Figure 2). For instance, 2'O-methylation of the $5^{\prime}$-cap structure abolishes interaction with RIG-I and MDA5, leading to the inability to recognize signaling of non-self RNA by the innate immune system. Conversely, virally transcribed RNA outside the nucleus generally exhibits a $5^{\prime}$ triphosphate, which can be recognized by RIG-I as "nonself" RNA.

TLR7, similarly to TLR3, is an inflammatory RBP and involved in the recognition of $2^{\prime}$-O-methylation status of RNA and causes the induction of inflammatory responses (Figure 2). Initial studies examining the role of RNA modifications in immune responses revealed that the base modifications, including 2'O-methylation at the ribose moiety on in vitro transcripts, prevented TLR activation. Conversely, an investigation into the role of RNA modifications in naturally occurring bacterial tRNA species demonstrated that tRNAs can induce the secretion of IFN- $\alpha$ in plasmacytoid dendritic cells (pDCs) through TLR7 signaling in a methylation status-dependent manner (107111). Importantly, studies in humans and mouse models have implicated pathways sensing these "non-self" RNA in obesity-induced inflammation. Mice lacking TLR7 exhibited an attenuation in metabolic inflammation and hyperglycemia on HFD (112). In addition, TLR7-deficient mice were protected from diet-induced atherosclerosis due to a reduction of atherosclerotic lesion inflammatory cytokines and systemic levels of serum amyloid A (113).

The expression level of TLR7 has been consistently very low in healthy human arterial specimens and higher in human atherosclerotic lesions, suggesting its involvement in atherosclerosis (114). Other studies have similarly reported that higher expression of TLR7 in atherosclerotic plaques and carotid arteries atheroma in human patients $(115,116)$. In the pathogenesis of metabolic diseases, a series of studies implicated endogenous RNA behaving like a pathogen which activated TLR7 through changes in the status of RNA modification. Recent studies identified minimal trinucleotide motifs within a 9-mer oligoribonucleotide that are capable TLR7 antagonists (117). Development of specific inhibitors of TLR7-sensing 


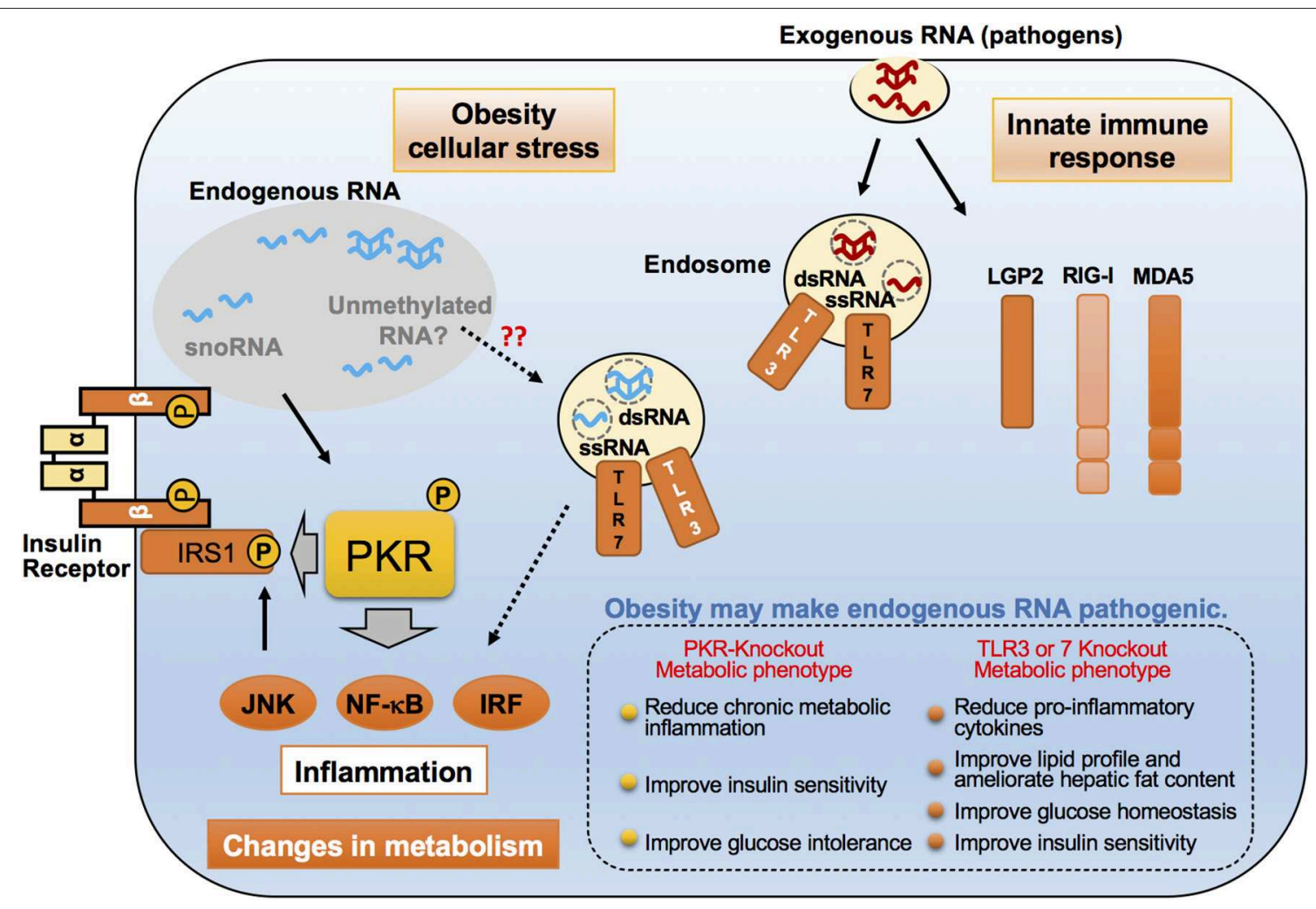

FIGURE 2 | Emerging roles of endogenous RNAs in inflammatory responses in obesity. Proposed molecular mechanisms for pro-inflammatory dsRNA-binding proteins such as PKR, TLR3, and TLR7, in recognizing exogenous and endogenous dsRNAs. These dsRNA-binding proteins distinguish and interact with virus-derived exogenous RNAs upon viral infection, and lead to the induction of an immune response. However, under cell stress conditions, such as saturated fatty acid exposure, these proteins are believed to sense changes in endogenous dsRNA networks through their interactions, thereby resulting in chronic inflammation that alters the metabolic state. These dsRNA-binding proteins accomplish this by phosphorylating the inhibitory serine found on insulin receptor substrate-1 (IRS-1), a critical insulin signaling component.

2'-O-methylated RNAs may facilitate future therapeutic strategies to manage complex immunometabolic disorders such as obesity and atherosclerosis.

\section{Diverse Roles of Small Nucleolar RNAs (snoRNAs) Involved in 2'-O-Methylation}

Small nucleolar RNAs (snoRNAs) are small non-coding RNAs that manage chemical modifications of other RNAs including ribosomal RNA (rRNA) and tRNA (118). SnoRNAs are stratified into two main groups according to their specific structural features: C/D box and H/ACA box (119). The majority of these snoRNAs localize in the nucleolus and canonically target nascent rRNAs for 2'-O-methylation (Figure 3) (106, 120). In addition, snoRNAs help regulate alternative splicing that leads to the creation of small RNA fragments that have microRNA (miRNA)-like activity (121-123). Intriguingly, snoRNAs are involved in mediating the lipotoxic effects in metabolically-driven stress responses (Figure 3). When cells are overloaded by pro-inflammatory saturated long chain fatty acids such as myristate, palmitate or stearate, snoRNAs [box C/D snoRNAs U32a (SNORD32a), U33 (SNORD33), U34 (SNORD34), and U35a (SNORD 35a)], located within introns 2, 4, and 6 of the targeted Rpl13a gene, are induced transcriptionally or by pre-mRNA stabilization in the cytoplasm, but not in the nucleoli. Inactivation of these snoRNAs by antisense oligonucleotides protects cells against palmitateinduced reactive oxygen species (ROS) production, ER stress, and subsequent cell death, independent of $2^{\prime}$-O-methylation of rRNA targets. A subsequent genome-wide shRNA-based screen recently identified nuclear export factor 3 (NXF3) as a transporter that can change the nucleo-cytoplasmic distribution pattern of these box C/D snoRNAs. Of note, these snoRNAs are involved in glucose intolerance and cholesterol trafficking mechanisms after treatment with fatty acids (120). For instance, knockdown of the Rpl13a snoRNAs U32a, U33, U34, and $\mathrm{U} 35 \mathrm{a}$ increased glucose-mediated insulin secretion in mice and systemic glucose tolerance (124), whereas snoRNA U60 (SNORD60) contributed to intracellular cholesterol trafficking, independent of its predicted function of methylating ribosomal RNAs (125). Interestingly, inflammation stimulates secretion of the Rpl13a snoRNAs from cultured macrophages through extracellular vesicles and these secreted snoRNAs travel in the circulation to functionally regulate $2^{\prime}$-O-methylation in distant tissues (Figure 3) (126), although it remains unclear 


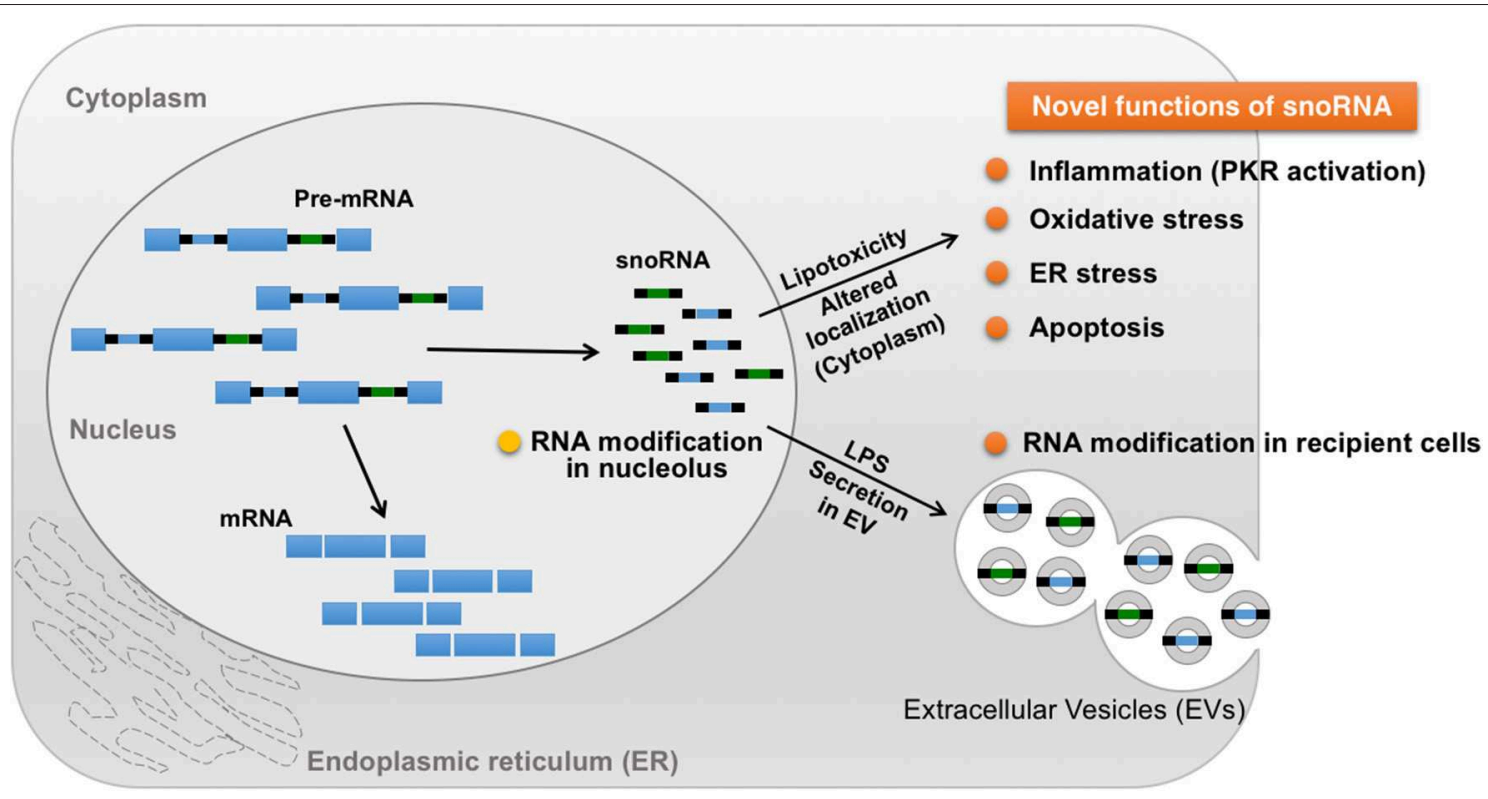

FIGURE 3 | Novel roles of snoRNA in response to metabolic and inflammatory stresses. A majority of snoRNAs are generated from intronic sequences during the splicing process. Under metabolically-driven stress conditions, levels of cytoplasmic snoRNAs are upregulated, thereby inducing oxidative stress, ER stress, and even cell death. In addition, LPS-treatment in macrophages enhances secretion of snoRNAs carried by extracellular vesicles (EV), leading to snoRNA-mediated RNA modification in distant EV recipient cells, which could contribute to the pathogenesis of systemic metabolic and inflammatory disorders in obesity.

whether these secreted snoRNAs trigger inflammatory responses in the recipient cells. These findings uncover a previously unappreciated role of snoRNAs linking intra- and inter-cellular signaling to systemic metabolic and inflammatory regulations. Additionally, microdeletions encompassing the SNORD116 cluster on the paternal chromosome $15 \mathrm{q} 11.2$ are associated with Prader-Willi syndrome (PWS), a syndrome in which affected individuals displaying profound food-seeking behavior and are, consequently, severely obese with or without diabetes (127). A recent animal study demonstrated that hypothalamic loss of SNORD116 recapitulates the hyperphagia of PWS (128). Although the molecular mechanism remains unresolved, these findings also suggest diverse roles of snoRNAs in the pathogenesis of obesity.

\section{PKR Interactions With Endogenous RNAs in Inflammatory Responses and Protein Translation}

Several RBPs, including TLR7, function as receptors for pathogen-associated molecular patterns (PAMPs) and dangerassociated molecular patterns (DAMPs) capable of inducing atypical inflammation under obese conditions (19, 129-131). PKR, also known as eukaryotic initiation factor 2-alpha kinase 2 (EIF2AK2), is another such sensor projected to be an adept regulator of innate immunity and downstream protein translation, against pathogen infection in higher eukaryotes (Figure 2) (132). PKR, together with PERK, HRI, and GCN2, is a member of the eIF $2 \alpha$ kinases and able to suppress protein translation through phosphorylation of $\operatorname{eIF} 2 \alpha$, which results in inhibition of guanine nucleotide exchange activity of the
eIF2B subunit $(133,134)$. PKR can also phosphorylate several other substrates, including inhibitor $\kappa \mathrm{B}(\mathrm{I} \kappa \mathrm{B})$, and stimulate multiple inflammatory signaling pathways such as c-Jun $\mathrm{N}$ terminal kinase (JNK), MAPKs, and nuclear factor $\kappa \mathrm{B}$ (NF$\kappa B)$ (135). The functions of PKR have been well-documented during viral infection, particularly RNA viruses, in which virusderived dsRNAs are recognized by PKR and bound to its $\mathrm{N}$ terminal two dsRNA-binding domains (dsRBDs), resulting in activation of the c-terminal intramolecular kinase domain (135). Importantly, these inflammatory and protein translational events are implicated in the pathogenesis of obesity, as demonstrated by activation of JNK, NF- $\mathrm{B}$, and phosphorylation of eIF2 $\alpha$, which are all induced in metabolic tissues, including liver and white adipose tissue, of obese mice and in humans (136). With these unique intrinsic molecular functions of PKR, it was perhaps not surprising that in obesity, PKR was found to be activated in metabolic tissues, and, upon activation, PKR induces JNK activation and eIF $2 \alpha$ phosphorylation, followed by the inhibitory serine phosphorylation of insulin receptor substrate1 (IRS-1), a critical insulin signaling component, by directly acting on IRS-1 or by indirectly activating JNK respectively (20). PKR activation was also observed in metabolic tissues of obese humans and, after bariatric surgery, PKR activation was reduced, followed by decreases in JNK and inhibitor of kappa $\beta$ kinase (IKK $\beta$ ) activation, as well as IRS-1 phosphorylation found within subcutaneous adipose tissue biopsied from these patients (137).

Intriguingly, PKR activation is induced by cellular stressors, including palmitate-induced lipotoxicity and endoplasmic reticulum (ER) stress, in the absence of pathogenic infection. The PKR activation induced by these cellular stresses, when 
compared to the robust activation by dsRNA or analogs like polyinosinic-polycytidylic acid (Poly(I:C)), are generally not drastically increased, but are sufficient to induce JNK activation and eIF2 $\alpha$ phosphorylation (20). These findings raise the possibility that PKR may ably sense nutrients or other cellular molecules, including endogenous RNA species, under metabolic stress conditions. Since PKR's defined RNA-binding activity is necessary for functional activation, a PKR RNA-binding defect variant (PKR-RM), which contains a point mutation at the lysine 64 residue, lost its ability to respond to palmitate, implicating a critical role of PKR's RNA-binding activity with endogenous dsRNAs during palmitate-induced PKR activation (20). Furthermore, immunoprecipitation (RIP)-seq analysis, wherein the authors of the study immunoprecipitated both PKR-RM and -WT, followed by purification and sequence analysis of bound RNAs, revealed that snoRNAs were in fact the majority of enriched RNAs that interacted with PKRWT (Figure 3) (138). Importantly, H/ACA box snoRNAs contain a common secondary structure made up of two hairpins and two single-stranded regions, termed a hairpinhinge-hairpin-tail structure, and this structure contains a dsRNA-like region (139). Furthermore, the important contribution of snoRNAs to PKR activation and regulation of metabolism was discerned by observing that palmitate exposure selectively interacted with PKR-WT only, and not with PKR-RM. Consistently, another study found that snoRNAs also can bind and activate PKR in vivo when overexpressed in cells (138).

In addition to interacting with snoRNAs, PKR can be activated by sensing endogenous RNAs, including inverted Alu repeats (IRAlus), mitochondrial tRNAs, and mRNAs, in mouse and human cells $(140,141)$. For instance, $5^{\prime}$-UTR of IFN- $\gamma$ mRNA mediates specific activation of PKR, leading to inhibition of IFN- $\gamma$ translation through a negative-feedback mechanism (142, 143), which could validate how the innate immune system overactivates upon sensing stress stimuli and then incrementally ameliorate the inflammatory effects of excessive IFN- $\gamma$ levels. Tumor necrosis factor alpha (TNF- $\alpha$ ), TNF- $\alpha 3^{\prime}$-UTR mRNA can also bind and activate PKR both in vivo and in vitro (144). Intriguingly, activation of PKR enables TNF- $\alpha$ mRNA splicing without blocking translation for efficient expression of TNF- $\alpha$ (145). These findings also implicate the physiological relevance of PKR activation in the inflammatory response to endogenous RNA species.

\section{PKR-Deficient Mouse Models in Obesity}

Although PKR appears to play a critical role in immunometabolic regulation and, indeed, several studies have shown that PKR-deficiency in mice exhibits beneficial immuno-metabolic phenotypes, contradicting observations have been reported (20, 146-149). These observations may be attributed, at least in part, to the use of different PKR-deficient mouse lines and their corresponding husbandry environment. The most widely used PKR-deficient mouse models carry a deletion in either the $\mathrm{N}$ terminal (N-PKR KO) or $\mathrm{C}$ terminal domain of PKR (C-PKR KO), resulting in expression of truncated forms of PKR (Figure 4). Specifically, both PKR-deficient mouse models are incomplete knockouts and retain partial functionality of PKR (150-152). The N-PKR KO model lacks two dsRBDs, but expresses a kinase domain that enables the phosphorylation of eIF2 $\alpha$. Conversely the C-PKR KO model lacks the kinase domain but express the two dsRBDs. Differences in signaling responses to specific stimuli have been observed in cells isolated from C-PKR $\mathrm{KO}$ or N-PKR KO mice.

Interestingly, the C-PKR KO mice on a mixed 129Sv x BALB/c background in a HFD study gained less weight and exhibited improved glucose tolerance and insulin sensitivity with decreased JNK activation and eIF2 $\alpha$ phosphorylation within metabolic tissues as compared to wild-type control mice (20). In addition, C-PKR KO mice were protected from intralipid-induced acute inflammation and insulin resistance (20). Subsequently, these mice were backcrossed to C57Bl/6 background, then crossed with genetically obese leptin-deficient mice $(o b / o b)$ to generate C-PKR KO-ob/ob mice. The beneficial metabolic phenotypes, including improved systemic glucose tolerance and insulin sensitivity, were also observed in C-PKR KO-ob/ob mice, while body weight was not affected (147). This combination of findings demonstrate that PKR plays a role as a critical regulator of metabolically-driven stresses and inflammation in obesity, making it a potential target for obesity-associated metabolic and inflammatory conditions.

In contrast, there are contradictory reports in metabolic phenotypes of N-PKR KO mice bred on a C57Bl/6 background. One study analyzing N-PKR KO mice in obesity validated the findings that N-PKR KO mice were protected from developing HFD-induced insulin resistance and glucose intolerance, due to a reduction in c-Jun $\mathrm{N}$-terminal kinase activity which resulted in improved insulin signaling within insulin-sensitive tissues (146). Conversely, another study reported that N-PKR KO mice did not show such protective phenotypes on HFD and there was only a mild influence on adipose tissue inflammation in $\mathrm{N}$ PKR KO mice (148). This study also reported no significant difference in inflammation levels when comparing WT and N-PKR KO macrophages after treatment with palmitic acid. Similarly, an independent study showed that N-PKR KO mice on HFD showed no significant differences in body weight or glucose levels compared to their control mice, although insulin levels were markedly decreased (149).

In another example of differences between the PKR-deficient mouse lines, N-PKR KO mice displayed severe disease-like of symptoms upon dextran sodium sulfate (DSS)-induced colitis (153), whereas C-PKR KO mice showed reduced sensitivity to DSS-induced colitis (154). These differences could be attributed to genetic/epigenetic differences, which may arise due to variations in independently maintained PKR KO mouse colonies, or possible differences in the gut microbiome (155). More importantly, it is known that cells in N-PKR KO mice still carry a kinase domain that enables the phosphorylation of PKR substrates including eIF2 $\alpha$ (151). As the kinase lacks the two regulatory dsRNA domains, the kinase activity is likely to be unregulated in vivo, and its substrates can be varied in different cells and under myriad cellular conditions. Of note, intact PKR has been observed to regulate intestinal inflammation and appears to be indispensable for DSS-induced 


\section{PKR structure}

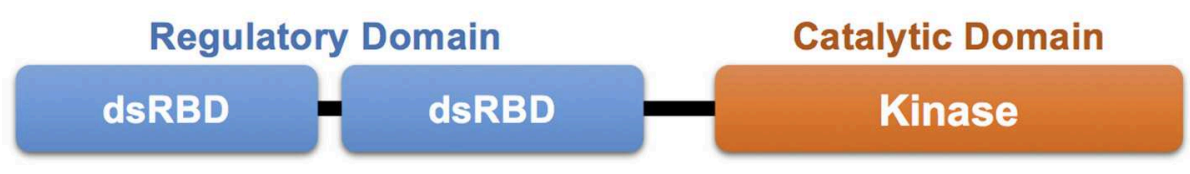

C-PKR KO line (expresses dsRBDs)

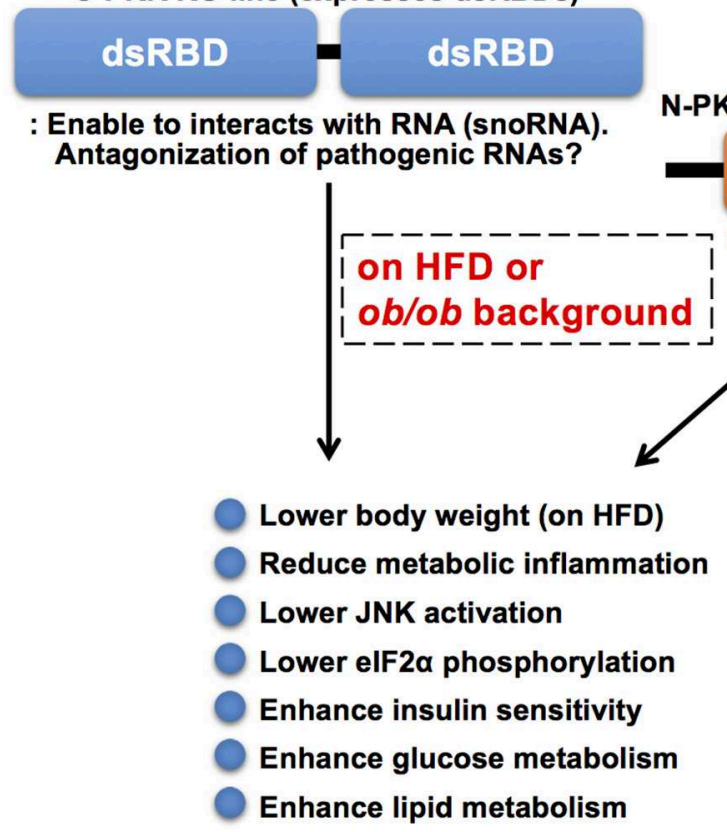

FIGURE 4 | Molecular structure and knockout mouse models of PKR. PKR is a serine/threonine kinase composed of a N-terminal regulatory domain containing two dsRBDs and a C-terminal catalytic (kinase) domain. The two dsRBDs bind to dsRNA leading to conformational change and kinase activation. There are two PKR-deficient mouse models used in the study of PKR function. Both PKR-deficient mouse models are incomplete knockouts and retain partial functionality of PKR. The N-PKR KO model lacks two dsRBDs, but expresses a kinase domain that enables the phosphorylation of elF2 $\alpha$. Conversely, the C-PKR KO model lacks the kinase domain, but expresses two dsRBDs. C-PKR KO mice showed beneficial metabolic phenotypes in the pathogenesis of obesity, however, there were contradictory findings in metabolic phenotypes observed in N-PKR KO mice. The differences may be due to environmental, genetic, and/or epigenetic factors that arise within different $\mathrm{N}-\mathrm{PKR} \mathrm{KO}$ mouse colonies.

colitis. These findings implicate a critical role of PKR in the gut microenvironment's immune function, which could systemically affect humoral immune responses and activate signaling pathways and molecules, including the kinase domain of N-PKR KO mice.

In the C-PKR KO mice, maintaining expression of dsRBDs, in addition to deletion of the kinase domain, of PKR may be associated with beneficial effects during the pathogenesis of obesity. The dsRBDs can still interact with endogenous RNAs, including snoRNAs, particularly under metabolicallydriven stress conditions $(138,151)$. Interaction of these PKR dsRBDs with RNAs in the absence of a kinase domain may result in neutralizing endogenous "pathological" RNAs such as the cytoplasmic snoRNAs triggering stress responses. It is noteworthy in several reports that treatment of PKR inhibitors, which generally target the kinase activity, show beneficial impacts on metabolism and diseases (156-160). Similar to the phenotypes observed in C-PKR KO mice, TLR3 deficiency, again a sensor of dsRNA associated with viral infections that stimulate innate immunity, improves glucose tolerance and reduces liver steatosis in obese mice maintained in specific pathogen-free conditions (21). Concurrent findings in PKR and TLR3 support the possibility that endogenous RNA species become "pathological" and are recognized by the dsRNA sensors, leading to the deterioration of systemic glucose and energy metabolism in obesity.

\section{Regulatory Machinery of miRNAs in Immuno-Metabolism}

Hypothetically, if nutrient and pathogen response systems are integrated, then involvement of pathogen sensors would be anticipated during metabolic regulation and stimulate the pursuit toward understanding the potential role of PKR in metabolism (19). Other than PKR, components of RNA-induced silencing complex (RISC) and RISC-loading complex (RLC) might assume such an integrative role, as recent evidence indicates that the host miRNA pathway represents just such an adaptive antiviral defense mechanism $(161,162)$. In addition, it has become obvious that regulatory mechanisms governed by miRNAs are vital for 


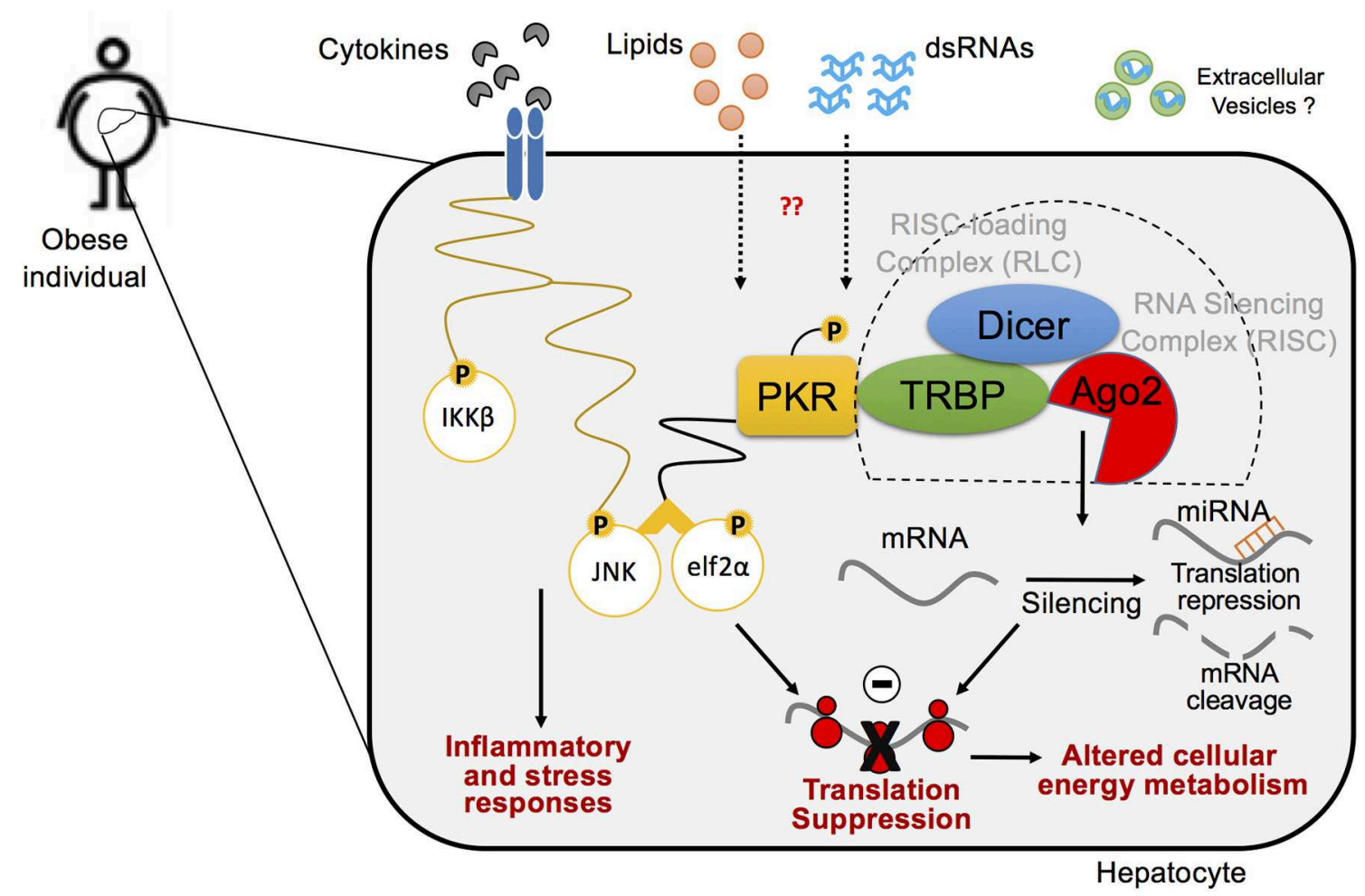

FIGURE 5 | A cross-talk between inflammatory pathways and RNA silencing machinery in hepatocytes in the pathogenesis of obesity. Biological interaction between inflammatory signaling pathway and protein translation regulation via PKR within the hepatocyte in metabolic stress responses. PKR is activated by lipid-mediated stress within obese metabolic tissues and induces concordant inflammatory responses, in which endogenous dsRNAs mediate PKR activation. Upon activation, PKR forms an inflammatory protein complex, using TRBP, Dicer, and RNA-induced silencing complex (RISC), which leads to protein translation suppression via phosphorylation of elf $2 \alpha$ and enhances inflammation via activation of JNK pathway. Ago2-mediated RNA silencing that regulates protein translation also plays a critical role in disputing metabolic homeostasis in the pathogenesis of obesity.

glucose maintenance and lipid homeostasis in metabolic tissues (163, 164). Mammalian Dicer, a main component of RLC, interacts with two closely related dsRNA binding proteins, TRBP (TAR RNA binding protein) and PACT (Protein activator of PKR), both of which regulate Dicer stability and contribute to RLC formation $(165,166)$. In addition, both molecules interact with PKR and are involved in inflammatory responses through regulation of PKR kinase activity and downstream activation of JNK, eIF2 $\alpha$, and IKK (147).

Intriguingly, the formation of a PKR complex featuring TRBP and Dicer is enhanced in metabolically-driven stress conditions and in the obese liver, where TRBP phosphorylation induced by MAPKs, such as JNK, contribute to the stabilization of Dicer and its interaction with PKR (Figure 5) (147, 167). Phosphorylation levels of TRBP are induced in obese livers when PKR is activated, and inactivation of hepatic TRBP in $o b / o b$ obese mice results in a significant reduction of JNK activity and eIF $2 \alpha$ phosphorylation, which coincides with the alleviation of systemic glucose intolerance, insulin resistance, and hepatic steatosis (147). Similar regulations were observed in cells undergoing palmitate-induced metabolic stress conditions. While there is still controversy surrounding the role of TRBP in regulating PKR activity $(168,169)$, these findings suggest that, in the setting of metabolic inflammation, MAPK-induced TRBP phosphorylation leads to PKR activation, followed by eIF $2 \alpha$ phosphorylation and JNK activation, as well as increased global miRNA expression, which are all observed simultaneously in obese liver.

\section{Role of RISC in Metabolic Regulation in Obese Liver}

TRBP is involved in glucose metabolism, at least in part, by regulating inflammatory responses in the obese liver, though questions remain as to whether another important function of TRBP regulating miRNA biogenesis and RNA silencing is involved in metabolic regulation. Recently, the vital role of hepatic miRNA-mediated events have been demonstrated in the pathogenesis of obesity and associated diseases (170). Global dysregulation of miRNA expression triggers in obese livers of humans and mice leads to the induction of the vast majority of miRNAs $(171,172)$, consistent with increased TRBP phosphorylation associated with enhanced Dicer stability and function. In addition, hepatic Dicerdeficient mice, lacking a gene encoding a central enzyme for miRNA generation, were characterized phenotypically as presenting with systemic metabolic disorders, hepatic lipid accumulation, and tumor development $(173,174)$. Therefore, it is reasonable and important to clarify the role of RISC in obesity-induced pathophysiology. 
In the liver, Ago1 and Ago2 are prominent members of the Argonaute family and the main components of RISC that carry out RNA silencing (175). Hepatic Agol appears to be unnecessary for obesity-induced pathophysiology, as it has been reported that deletion of hepatic Agol had no significant effect on weight gain, glucose tolerance, or insulin sensitivity under obese conditions (27). Conversely, hepatic Ago2-deficiency significantly aided and improved glucose metabolism, even in conditions of insulin receptor antagonist treatment, HFD challenge, and deletion of hepatic $5^{\prime}$-AMP-activated protein kinase catalytic subunit alpha1 (AMPK $\alpha 1$ ) which regulates energy metabolism (27). Ago2 has been shown to regulate the expression of a number of specific miRNAs including miR-802, miR-103/107, and miR-148a/152, which deteriorate glucose and lipid metabolism after being generated by Ago2's unique "slicer" activity (27, 171, 176-178). In addition, Ago2-deficient hepatocytes are characterized as having enhanced mitochondrial oxidation and ATP consumption, which appears to be associated with less weight gain and enhanced energy expenditure observed in hepatic Ago2-deficient mice (27). An independent study also demonstrated that hepatic Ago2deletion from $o b / o b$ mice led to reduced body weight with lowered basal and fasted blood glucose levels, as well as improved insulin sensitivity (179). Hepatic Ago2-deficiency resulted in

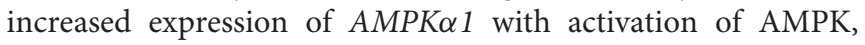
a critical regulator of energy metabolism, reduced expression of miR-148a, and enhanced general protein translation that contributed to ATP consumption and AMPK activation (27, 179). These findings suggest that Ago2 has the unique function of regulating energy production and consumption in the liver, and these data point to hepatic Ago2-mediated RNA silencing being a key regulator of energy metabolism under obesity-related metabolic conditions.

Of note, the distribution of RNA modifications was enriched in the untranslated regions of mRNAs and near Argonaute protein binding regions, which indicates a potential role of RNA modification in RNA silencing (180). For instance, it was previously reported that the binding sites for the Argonaute proteins overlap within the 3 UTRs of the m6A residues (181). In addition, a significant number of 5-methylcytosine $(\mathrm{m} 5 \mathrm{C})$ candidate sites are located within mRNA containing binding regions for the Argonaute proteins (182). These results demand further study to determine the interconnected role of RNA modification and Argonaute proteins toward metabolic regulation, as changes in these modifications occurring in obesity may impact the post-transcriptional gene regulation via Ago2mediated RNA silencing.

\section{Metabolic Regulation Through the CCR4-NOT Complex}

A poly(A) sequence at the $3^{\prime}$ end of mRNA tail contributes to post-transcriptional gene regulation by acting on mRNA metabolic stability and frequency of translation (183). Shortening of poly(A) tails by deadenylation induces mRNA decay from $3^{\prime}$ end (184). The major deadenylase in eukaryotic cells is the CCR4NOT complex, which is composed of Cnot1-Cnot3, Cnot6, Cnot6L, and Cnot7-Cnot11 (Figure 6) (185-187). Furthermore, the CCR4-NOT complex is involved in post-transcriptional silencing via interactions with RISC $(188,189)$. Importantly, the CCR4-NOT complex is implicated during development of metabolic diseases such as obesity, diabetes, liver steatosis, and energy metabolism by metabolizing mRNAs of energy metabolic-associated genes and thus reducing their expression levels through deadenylase activity (190). Mice haplodeficient in Cnot3 that were fed a HFD, or in an ob/ob background, exhibited reduced hepatic and adipose fat deposition, improved glucose tolerance, and enhanced insulin sensitivity (190). Mechanistically, in these Cnot3 haplodeficient conditions, expression levels of pyruvate dehydrogenase kinase $4(P d k 4)$ and insulin-like growth factor binding protein 1 (Igfbp1) mRNAs were higher with longer poly $(\mathrm{A})$ tails when compared to controls due to reduced deadenylation activity (190). Liver-specific Cnot 3 conditional deletion resulted in reductions in liver mass that coincided with severe inflammation, histological damage, apoptosis, and induced gene expression of immature liver genes, immune responses, and cell-cycle regulation (191). Inhibition of hepatic CCR4-NOT activity by deletion of the deadenylase catalytic subunit CNOT6L led to increased mRNA expression of Fgf21, a hormone secreted mainly from the liver and involved in systemic glycemic control, due to inactivation of deadenylation. Expression of Fgf21 resulted in increased serum FGF21 levels and improvements of diet-induced metabolic conditions and energy expenditure (192). These findings suggest that the CCR4NOT complex-mediated mRNA decay mechanism is critical for proper liver function and systemic metabolic regulation, thus modulating the systemic metabolic-energy homeostasis and describing the strong association between post-transcriptional gene silencing and metabolism (192).

In addition to the role of CCR4-NOT complex in the liver, this complex apparently plays a vital regulatory role controlling adipocyte differentiation and functions. Adipocytespecific Cnot3 conditional disruption results in lipodystrophy with hyperinsulinemia, hyperglycemia, insulin resistance, and glucose intolerance (193). Similar to the case of liver-specific Cnot 3 conditional deletion, robust inflammation with activated macrophages was observed in the adipose tissue of Cnot3deficiency, suggesting that deregulation of deadenylation causes stress and inflammatory responses. Cnot7, together with the members of Tob/BTG protein family, transducer of ERBB2 (Tob), regulates mRNA expression of uncoupling protein 1 (Ucp1), the main driver of non-shivering thermogenesis, in inguinal white adipose tissue (iWAT) (194). The Tob/BTG protein family is implicated in the regulation of mRNA decay via binding to the CCR4-NOT complex through direct interaction with Cnot7 (195-197). Tob interacts with BRF, the TTP family of ARE-recognizing protein, at the AU-rich region in the $3^{\prime}$-UTR of Ucp1 mRNA, resulting in recruitment of Cnot7 deadenylase to Ucp 1 for its destabilization. Therefore, the absence of Cnot7 or Tob results in higher levels of Ucp1 mRNA in iWAT. The increased Ucp1 appears to protect from diet-induced obesity and associated complications in HFD-fed mice lacking Cnot7 and/or Tob deficiency (194). Conversely, Tob2, a member of the Tob/BTG protein family that interacts with Cnot7, inhibits adipogenesis, and its deficiency in 


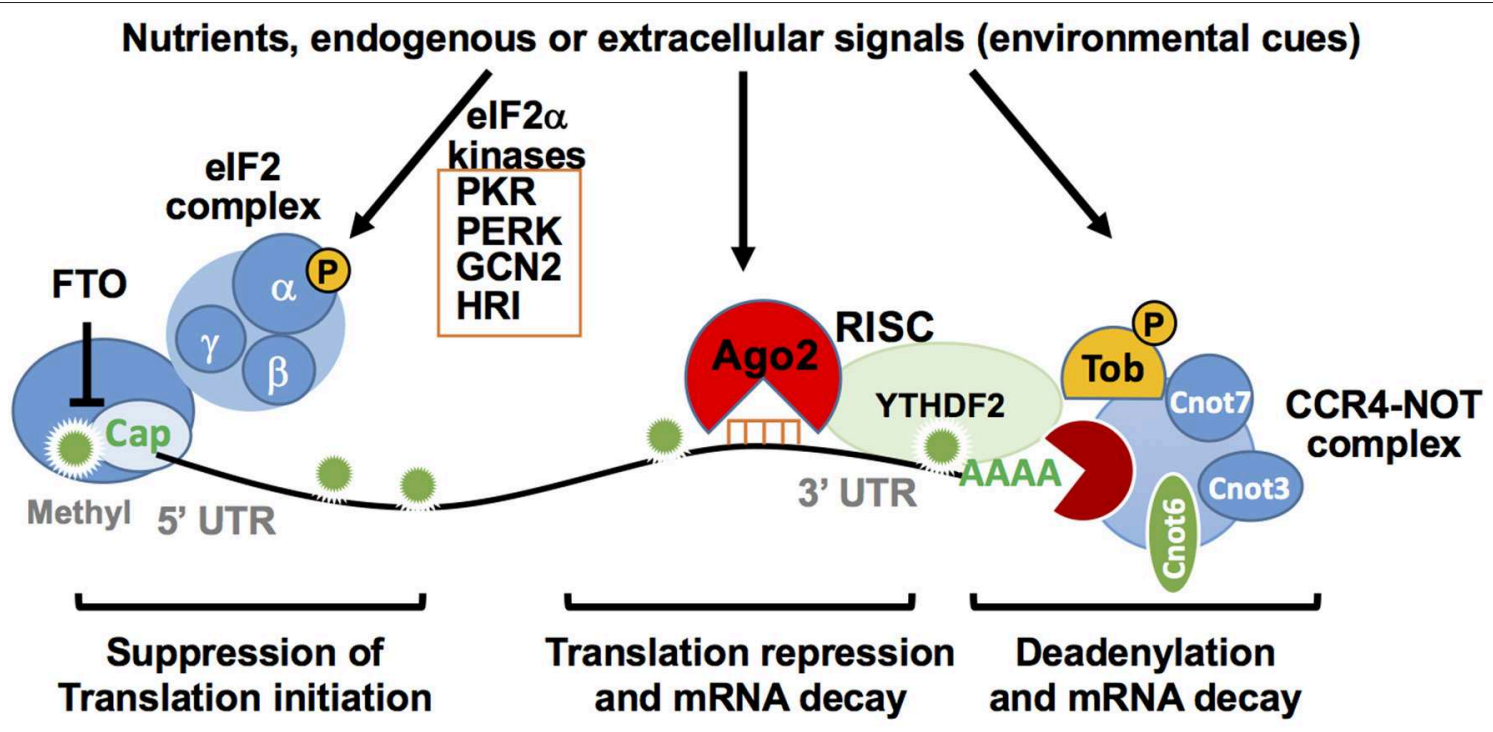

In obesity, alteration of:

\begin{tabular}{|c|c|}
\hline $\begin{array}{l}\text { Global } \\
\text { protein translation }\end{array}$ & $\begin{array}{c}\text { Specific } \\
\text { metabolic proteins }\end{array}$ \\
\hline \multicolumn{2}{|c|}{ Metabolic dysregulation } \\
\hline $\begin{array}{l}\text { Lowered cellular } \\
\text { energy metabolism }\end{array}$ & $\begin{array}{l}\text { Malfunction of } \\
\text { specific pathways }\end{array}$ \\
\hline
\end{tabular}

RNA methylation impacts:

Development of metabolic diseases

Association of initiation complex with mRNA

RNA silencing efficiency

Accessibility of CCR4NOT complex to polyA.

FIGURE 6 | Post-transcriptional regulation of mRNA translation repression elF2a complex, Ago2-mediated RNA silencing, and decay and deadenylation via CCR4-NOT complex in metabolic regulation. RNA stability is increased by $\mathrm{m}^{7} \mathrm{Gppp}$ cap-adjacent $\mathrm{m}^{6} \mathrm{Am}$. The $\mathrm{m}^{7} \mathrm{Gppp}$ cap is recognized by the protein initiation complex for protein translation. Conversely, elF2a phosphorylation induced by elF2a kinases in response to a variety of environmental cues results in inhibition of protein translation. Removal of the $\mathrm{m}^{7} \mathrm{Gppp}$ cap by the decapping enzyme DCP2 is a key step in mRNA decay. Ago2-mediated RNA silencing represses mRNA translation and induces its decay. The CCR4-NOT protein complex binds and deadenylates the poly(A) tail of target mRNA to stimulate mRNA decay. Ago2 RNA silencing machinery interacts with CCR4-NOT complex resulting in rapid mRNA decay and/or translation repression. TOB protein recruits CCR4-NOT deadenylase to a specific mRNA poly(A) tail by direct binding to Cnot7. Functions of these components are highly integrated into cellular metabolic homeostasis, at least in part, by regulating the efficiency of global protein translation and/or expression of specific metabolic proteins. Altered RNA methylation patterns on mRNA induced in obesity may affect these processes and thereby disrupt cellular metabolic homeostasis.

mice induces increased adiposity. Tob2 blocks BMP2-induced Smad1/5 phosphorylation by directly interacting with Smad6, which sequentially suppresses mRNA expression of Ppar $\gamma-2$, a critical regulator of adipogenesis, although involvement of Tob2 in the regulation of Ppar -2 mRNA stability remains elusive (198). These findings indicate that the CCR4-NOT complex-mediated post-transcriptional dysregulation of selective metabolic genes, and possibly global protein translation, are strongly associated with, and contribute to, the development of obesity and obesity-related disorders.

\section{Therapeutic Implications of Regulating the RNA-RBP Interaction}

The complete understanding of the pathophysiology of obesity and the role of RNA-RBPs within the context of disease are still under investigation. However, there has been emerging in vitro, ex vivo, and in vivo experimental data highlighting potential underlying mechanisms of RNA-RBPs that might be crucial to answering important questions during the study of immunemetabolic dysregulation. As previously described, RNA-RBPs are considered novel players essential for the association between abnormal immune system response, posttranscriptional gene regulation, and metabolic dysfunction both at the tissue-specific and systemic scale. Clearly, it could be hypothesized that specific pharmacological inhibitors against particular RNA-RBPs would restore normal insulin signaling, glucose and lipid metabolism, and ameliorate inflammation and fibrosis of metabolic tissues, such as is observed in obesity-induced steatohepatitis. As a proof of principle, small chemical inhibitors were tested to block the activity of PKR, such as imoxin and 2-aminopurine (199, 200), and when used under immune-metabolic stress conditions resulted in improvements in immune-metabolic phenotypes in a mouse model (156). Additionally, new chemical agents are being developed that antagonize the miRNA-Ago 2 protein 
complex, including anti-miRNA-Ago2 and tiny locked nucleic acids (LNAs), by binding to the active site of Ago2 protein and seed region of miRNAs, thereby resulting in functional inhibition of Ago2-mediated miRNAs (201-203). It is further reported that inhibitors of miRNA binding to Ago2 (miRISC loading inhibitors) were used in experimental studies which mimic Ago2 small hairpin RNA, although these have not been validated in clinical settings $(204,205)$. Collectively, these findings and efforts targeting specific RNA-RBP interactions may be useful toward developing a novel class of drugs designed to treat obesityassociated metabolic disorders.

Within the above context, pharmacological inhibition of upregulated miRNAs that contribute to the onset and propagation of obesity toward type 2 diabetes could potentially be employed as an alternative medical therapy, in which external artificial agents will be administered to counteract the miRNAs-induced molecular defects in obesity. For example, antisense oligonucleotides (AMOs) have been designed that bind to target miRNA and inhibit the function of miRNA by preventing its binding to target $\mathrm{mRNA}$, followed by sequestration and/or RNase-mediated degradation. Currently, pharmaceutical laboratories have produced several generations of AMOs in order to improve the pharmacokinetic parameters with less toxicity by engineering AMOs containing other modifications, such as $2^{\prime}$-fluoro and/or $2^{\prime}$ Omethoxyethyl, as well as $2^{\prime}$-O-methyl modifications, phosphorothioate bonds, and a $3^{\prime}$ end cholesterol tail seen in the first AMO generation (206-208). By taking advantage of the approach, it was demonstrated that specific miRNAs, such as miR-802, play a vital role in obesity-related hepatic insulin insensitivity and when reduced in mice by the AMOs they regained normal metabolic function (171). In a clinical setting, oligonucleotide inhibitors of liver-specific miR-122, RG-101 and Miravirsen, were used for clinical trials to treat patients with Hepatitis $\mathrm{C}$ virus $(\mathrm{HCV})$ by targeting the $5^{\prime}$ end of miR-122 to diminish viral replication with certain results, thereby indicating the safety and effectiveness of the drug (209-212). This trial gives hope for the development of a new generation of drugs targeting specific RNAs.

Even in the presence of potentially effective, though limited, therapeutics targeting specific RNAs, further studies are required to elucidate the molecular mechanisms underlying the development of immune-metabolic disorders. Nonetheless, there is clear evidence that RNA-RBP networks play a critical role in the regulation of tissue-specific and/or whole-body glucose metabolism and inflammation, and that novel approaches targeting RNA-RBPs network in the setting of metabolic disorders will facilitate clinical research toward the identification of effective medical therapies for treating obesity and its associated metabolic diseases.

\section{SUMMARY}

Knowledge of the role of RNA networks associated with RNA modifications and RNA-RBP interactions in inflammatory and metabolic regulation in obesity is limited. However, accumulating evidence has shed light on how RNA networks dynamically affect metabolic, developmental, and inflammatory mechanisms in the pathogenesis of obesity-associated disorders. Indeed, functional changes of additional RBPs, including but not limited to LIN28A, IGF2BP2/IMP2, and HuR, are linked to the development of metabolic diseases (213-215). RNA methylation influences and fate maps RNA toward translation, degradation, or even sequestration inside cellular compartments. Therefore, reversible RNA modification, particularly RNA methylation, represents a new epigenetic marker, similar to reversible DNA modifications, that provides clues to adaptive cellular responses associated with metabolic changes in response to distinct exogenous or endogenous stress stimuli including excessive nutrients, toxins, and microbial infections $(216,217)$. RNA modifications could affect RNA-RBP networks and emerging biological events, including RNA export and transport, RNA cleavage, maturation, and stability, as well as functional changes in RBPs (218). Unveiling these epigenetic regulatory roles of the RNA networks is important to clarify the pathogenesis of chronic diseases including, but not limited to, obesity, cardiovascular, aging, and autoimmune diseases, where the exact molecular mechanisms are still ill defined.

While RNA modifications are generally considered a finetuning process of cellular homeostasis, prolonged external cues, including chronic HFD-feeding, may gradually accumulate erroneous RNA modifications that drive the cell fate toward chronic and low-grade inflammatory conditions which are well-observed cellular features in obesity. This concept is supported by evidence that several inflammatory RBPs, including TLR3, TLR7, and PKR, are involved in the induction of obesity-associated chronic inflammation. As mRNA methylation modification could influence post-transcriptional gene silencing and control targeted gene expression, e.g., through affecting interactions with mRNA/miRNA/Ago proteins complex, there may be specific types and modifications of RNAs that activate metabolic and inflammatory programs in the pathogenesis of obesity.

Current technical advances have allowed us to investigate quantitative changes in many types of RNA species; either coding or non-coding RNA levels, and methylation status (219-221). However, the challenge is to precisely analyze the type of modification, the degree of modifications, and to predict their biological significance, particularly the effect of these changes on the RNA's secondary structure, localization, and interactions with specific RBPs. These important insights would then lead to the development of novel therapeutics to change RNA-RBP interactions in obesity and T2D. Nonetheless, to investigate the components that manage RNA specificity, regulatory mechanisms, and functions of RBPs, it is important to prioritize methods that characterize direct endogenous protein-RNA interactions. In the past decade, several RIP methods, including cross-linking and immunoprecipitation (CLIP) and methylation individual-nucleotide-resolution CLIP (miCLIP), have been developed to determine the in vivo RNA targets of RBPs (221-223). Utilization of RBPs known to be involved in inflammatory and metabolic diseases to identify the "pathological" RNAs by RIP would provide unique approaches for better understanding the molecular mechanisms of chronic inflammatory diseases. Such efforts might pave the way for novel 
therapeutic and pharmacological targets and/or interventions for combating obesity-induced sequelae.

\section{AUTHOR CONTRIBUTIONS}

All authors listed have made a substantial, direct and intellectual contribution to the work, and approved it for final version.

\section{REFERENCES}

1. Afshin A, Forouzanfar MH, Reitsma MB, Sur P, Estep K, Lee A, et al. Health effects of overweight and obesity in 195 countries over 25 years. N Engl J Med. (2017) 377:13-27. doi: 10.1056/NEJMoa1614362

2. Zeggini E, Weedon MN, Lindgren CM, Frayling TM, Elliott KS, Lango $\mathrm{H}$, et al. Replication of genome-wide association signals in UK samples reveals risk loci for type 2 diabetes. Science. (2007) 316:133641. doi: 10.1126/science.1142364

3. Scott LJ, Mohlke KL, Bonnycastle LL, Willer CJ, Li Y, Duren WL, et al. A genome-wide association study of type 2 diabetes in Finns detects multiple susceptibility variants. Science. (2007) 316:1341-5. doi: 10.1126/science. 1142382

4. Loos RJ, Yeo GS. The bigger picture of FTO: the first GWAS-identified obesity gene. Nat Rev Endocrinol. (2014) 10:51-61. doi: 10.1038/nrendo.2013.227

5. Dina C, Meyre D, Gallina S, Durand E, Korner A, Jacobson P, et al. Variation in FTO contributes to childhood obesity and severe adult obesity. Nat Genet. (2007) 39:724-6. doi: 10.1038/ng2048

6. Kloting N, Schleinitz D, Ruschke K, Berndt J, Fasshauer M, Tonjes A, et al. Inverse relationship between obesity and FTO gene expression in visceral adipose tissue in humans. Diabetologia. (2008) 51:6417. doi: 10.1007/s00125-008-0928-9

7. Berulava T, Horsthemke B. The obesity-associated SNPs in intron 1 of the FTO gene affect primary transcript levels. Eur J Hum Gene.t. (2010) 18:1054-6. doi: 10.1038/ejhg.2010.71

8. Stratigopoulos G, Padilla SL, LeDuc CA, Watson E, Hattersley AT, McCarthy MI, et al. Regulation of Fto/Ftm gene expression in mice and humans. Am J Physiol Regul Integr Comp Physiol. (2008) 294:R1185R1196. doi: 10.1152/ajpregu.00839.2007

9. Merkestein M, Laber S, McMurray F, Andrew D, Sachse G, Sanderson J, et al. FTO influences adipogenesis by regulating mitotic clonal expansion. Nat Commun. (2015) 6:6792. doi: 10.1038/ncomms7792

10. Cao G, Li HB, Yin Z, Flavell RA. Recent advances in dynamic m6A RNA modification. Open Biol. (2016) 6:160003. doi: 10.1098/rsob.160003

11. Zhao X, Yang Y, Sun BF, Shi Y, Yang X, Xiao W, et al. FTOdependent demethylation of N6-methyladenosine regulates mRNA splicing and is required for adipogenesis. Cell Res. (2014) 24:1403-19. doi: 10.1038/cr.2014.151

12. Zhang M, Zhang Y, Ma J, Guo F, Cao Q, Zhang Y, et al. The demethylase activity of FTO (Fat mass and obesity associated protein) is required for preadipocyte differentiation. PloS ONE. (2015) 10:e0133788. doi: 10.1371/journal.pone.0133788

13. Zhao X, Yang Y, Sun BF, Zhao YL, Yang YG. FTO and obesity: mechanisms of association. Curr Diab Rep. (2014) 14:486. doi: 10.1007/s11892-014-0486-0

14. Wei J, Liu F, Lu Z, Fei Q, Ai Y, He PC, et al. Differential m(6)A, m(6)Am, and $\mathrm{m}(1) \mathrm{A}$ demethylation mediated by FTO in the cell nucleus and cytoplasm. Mol Cell. (2018) 71:973-985.e5. doi: 10.1016/j.molcel.2018.08.011

15. Mauer J, Luo X, Blanjoie A, Jiao X, Grozhik AV, Patil DP, et al. Reversible methylation of m(6)Am in the 5' cap controls mRNA stability. Nature. (2017) 541:371-5. doi: 10.1038/nature21022

16. Wang $\mathrm{X}, \mathrm{He}$ C. Dynamic RNA modifications in posttranscriptional regulation. Mol Cell. (2014) 56:5-12. doi: 10.1016/j.molcel.2014.09.001

17. Zhao BS, Roundtree IA, He C. Post-transcriptional gene regulation by mRNA modifications. Nat Rev Mol Cell Biol. (2017) 18:31-42. doi: 10.1038/nrm.2016.132

\section{ACKNOWLEDGMENTS}

We thank the Nakamura lab members and Dr. Vivian Hwa for their scientific input and discussion. This work was supported by National Institute of Health (NIH) R01DK107530 (TN) and P30DK078392 for the Digestive Disease Research Core Center in Cincinnati.

18. Vallerie SN, and Hotamisligil GS. The role of JNK proteins in metabolism. Sci Transl Med. (2010). 2:60rv5. doi: 10.1126/scitranslmed.3001007

19. Hotamisligil GS. Inflammation, metaflammation and immunometabolic disorders. Nature. (2017) 542:177-85. doi: 10.1038/nature21363

20. Nakamura T, Furuhashi M, Li P, Cao H, Tuncman G, Sonenberg N, et al. Double-stranded RNA-dependent protein kinase links pathogen sensing with stress and metabolic homeostasis. Cell. (2010) 140:33848. doi: 10.1016/j.cell.2010.01.001

21. Wu LH, Huang CC, Adhikarakunnathu S, San Mateo LR, Duffy KE, Rafferty $\mathrm{P}$, et al. Loss of toll-like receptor 3 function improves glucose tolerance and reduces liver steatosis in obese mice. Metabol Clin Exp. (2012) 61:163345. doi: 10.1016/j.metabol.2012.04.015

22. Konner AC, Bruning JC. Toll-like receptors: linking inflammation to metabolism. Trends Endocrinol Metab. (2011) 22:1623. doi: 10.1016/j.tem.2010.08.007

23. Kim SJ, Choi Y, Choi YH, Park T. Obesity activates toll-like receptormediated proinflammatory signaling cascades in the adipose tissue of mice. $J$ Nutr Biochem. (2012) 23:113-22. doi: 10.1016/j.jnutbio.2010.10.012

24. Hotamisligil GS. Inflammation and metabolic disorders. Nature. (2006) 444:860-7. doi: 10.1038/nature05485

25. Hotamisligil GS, Erbay E. Nutrient sensing and inflammation in metabolic diseases. Nat Rev Immunol. (2008) 8:923-34. doi: 10.1038/nri2449

26. Xing Z, Ma WK, Tran EJ. The DDX5/Dbp2 subfamily of DEAD-box RNA helicases. Wiley Interdisc Rev RNA. (2019) 10:e1519. doi: 10.1002/ wrna.1519

27. Zhang C, Seo J, Murakami KE, Salem SB, Bernhard E, et al. Hepatic Ago2-mediated RNA silencing controls energy metabolism linked to AMPK activation and obesity-associated pathophysiology. Nat Commun. (2018). 9:3658. doi: 10.1038/s41467-018-05870-6

28. Andreasen CH, Stender-Petersen KL, Mogensen MS, Torekov SS, Wegner L, Andersen G, et al. Low physical activity accentuates the effect of the FTO rs9939609 polymorphism on body fat accumulation. Diabetes. (2008) 57:95-101. doi: 10.2337/db07-0910

29. Muller TD, Hinney A, Scherag A, Nguyen TT, Schreiner F, Schafer H, et al. Fat mass and obesity associated' gene (FTO): no significant association of variant rs9939609 with weight loss in a lifestyle intervention and lipid metabolism markers in German obese children and adolescents. BMC Med Genet. (2008) 9:85. doi: 10.1186/1471-2350-9-85

30. Kilpelainen TO, Qi L, Brage S, Sharp SJ, Sonestedt E, Demerath E, et al. Physical activity attenuates the influence of FTO variants on obesity risk: a meta-analysis of 218,166 adults and 19,268 children. PLoS Med. (2011) 8:e1001116. doi: 10.1371/journal.pmed.1001116

31. Ruiz JR, Labayen I, Ortega FB, Legry V, Moreno LA, Dallongeville J, et al. Attenuation of the effect of the FTO rs9939609 polymorphism on total and central body fat by physical activity in adolescents: the HELENA study. Arch Pediatr Adolesc Med. (2010) 164:328-33. doi: 10.1001/archpediatrics.2010.29

32. Curti ML, Rogero MM, Baltar VT, Barros CR, Siqueira-Catania A, Ferreira SR. FTO T/A and peroxisome proliferator-activated receptorgamma Pro12Ala polymorphisms but not ApoA1 -75 are associated with better response to lifestyle intervention in Brazilians at high cardiometabolic risk. Metab Syndr Relat Disord. (2013) 11:169-76. doi: 10.1089/met.2012.0055

33. de Luis DA, Aller R, Izaola O, de la Fuente B, Conde R, Sagrado MG, et al. Evaluation of weight loss and adipocytokines levels after two hypocaloric diets with different macronutrient distribution in obese subjects with rs9939609 gene variant. Diabetes Metab Res Rev. (2012) 28:663-8. doi: $10.1002 / \mathrm{dmr} .2323$ 
34. de Luis DA, Aller R, Conde R, Izaola O, Gonzalez Sagrado M, Castrodeza Sanz J. The rs9939609 gene variant in FTO modified the metabolic response of weight loss after a 3-month intervention with a hypocaloric diet. J Investig Med. (2013) 61:22-6. doi: 10.2310/JIM.0b013e318276161d

35. Razquin C, Martinez JA, Martinez-Gonzalez MA, Bes-Rastrollo M, Fernandez-Crehuet J, Marti A. A 3-year intervention with a Mediterranean diet modified the association between the rs9939609 gene variant in FTO and body weight changes. Int J Obes. (2010) 34:266-72. doi: 10.1038/ijo.2009.233

36. McCaffery JM, Papandonatos GD, Huggins GS, Peter I, Kahn SE, Knowler WC, et al. FTO predicts weight regain in the Look AHEAD clinical trial. Int J Obes. (2013) 37:1545-52. doi: 10.1038/ijo.2013.54

37. Lappalainen TJ, Tolppanen AM, Kolehmainen M, Schwab U, Lindstrom J, Tuomilehto J, et al. The common variant in the FTO gene did not modify the effect of lifestyle changes on body weight: the Finnish diabetes prevention study. Obesity. (2009) 17:832-6. doi: 10.1038/oby.2008.618

38. Rauhio A, Uusi-Rasi K, Nikkari ST, Kannus P, Sievanen H, Kunnas T. Association of the FTO and ADRB2 genes with body composition and fat distribution in obese women. Maturitas. (2013) 76:165-71. doi: 10.1016/j.maturitas.2013.07.004

39. Verhoef SP, Camps SG, Bouwman FG, Mariman EC, Westerterp KR. Genetic predisposition, dietary restraint and disinhibition in relation to short and long-term weight loss. Physiol Behav. (2014) 128:247-51. doi: 10.1016/j.physbeh.2014.02.004

40. Woehning A, Schultz JH, Roeder E, Moeltner A, Isermann B, Nawroth PP, et al. The A-allele of the common FTO gene variant rs9939609 complicates weight maintenance in severe obese patients. Int J Obes. (2013) 37:135-9. doi: 10.1038/ijo.2012.14

41. Li H, Wu Y, Loos RJ, Hu FB, Liu Y, Wang J, et al. Variants in the fat mass- and obesity-associated (FTO) gene are not associated with obesity in a Chinese Han population. Diabetes. (2008) 57:264-8. doi: 10.2337/db07-1130

42. Demerath EW, Lutsey PL, Monda KL, Linda Kao WH, Bressler J, Pankow JS, et al. Interaction of FTO and physical activity level on adiposity in AfricanAmerican and European-American adults: the ARIC study. Obesity. (2011) 19:1866-72. doi: 10.1038/oby.2011.131

43. Zou ZC, Mao JL, Shi YY, Chen JH, Wang LS, Cai W. Effect of exercise combined with dietary intervention on obese children and adolescents associated with the FTO rs9939609 polymorphism. Eur Rev Med Pharmacol Sci. (2015) 19:4569-75.

44. Muc M, Padez C, Manco L. Influence of physical activity on the association between the FTO variant rs 9939609 and adiposity in young adults. Am J Hum Biol. (2015) 27:734-8. doi: 10.1002/ajhb.22712

45. Scuteri A, Sanna S, Chen WM, Uda M, Albai G, Strait J, et al. Genome-wide association scan shows genetic variants in the FTO gene are associated with obesity-related traits. PLoS Genet. (2007) 3:e115. doi: 10.1371/journal.pgen.0030115

46. Haupt A, Thamer C, Machann J, Kirchhoff K, Stefan N, Tschritter O, et al. Impact of variation in the FTO gene on whole body fat distribution, ectopic fat, and weight loss. Obesity. (2008) 16:1969-72. doi: 10.1038/oby.2008.283

47. Mitchell JA, Church TS, Rankinen T, Earnest CP, Sui X, Blair SN. FTO genotype and the weight loss benefits of moderate intensity exercise. Obesity. (2010) 18:641-3. doi: 10.1038/oby.2009.311

48. Dlouha D, Suchanek P, Lanska V, Hubacek JA. Body mass index change in females after short-time life style intervention is not dependent on the FTO polymorphisms. Physiol Res. (2011) 60:199-202.

49. Zhang X, Qi Q, Zhang C, Smith SR, Hu FB, Sacks FM, et al. FTO genotype and 2-year change in body composition and fat distribution in response to weight-loss diets: the POUNDS LOST trial. Diabetes. (2012) 61:3005-11. doi: $10.2337 / \mathrm{db} 11-1799$

50. Robiou-du-Pont A, Bonnefond L, Yengo E, Vaillant S, Lobbens E, Durand J, et al. Contribution of 24 obesity-associated genetic variants to insulin resistance, pancreatic beta-cell function and type 2 diabetes risk in the French population. Int J Obes. (2013) 37:980-5. doi: 10.1038/ijo.2012.175

51. Reddon H, Gerstein HC, Engert JC, Mohan V, Bosch J, Desai D, et al. Physical activity and genetic predisposition to obesity in a multiethnic longitudinal study. Sci Rep. (2016) 6:18672. doi: 10.1038/srep18672

52. Vimaleswaran KS, Li S, Zhao JH, Luan J, Bingham SA, Khaw KT, et al. Physical activity attenuates the body mass index-increasing influence of genetic variation in the FTO gene. Am J Clin Nutr. (2009) 90:425-8. doi: 10.3945/ajen.2009.27652

53. Ahmad S, Rukh G, Varga TV, Ali A, Kurbasic A, Shungin D, et al. Gene $\mathrm{x}$ physical activity interactions in obesity: combined analysis of 111,421 individuals of European ancestry. PLoS Genet. (2013) 9:e1003607. doi: 10.1371/journal.pgen.1003607

54. Frayling TM, Timpson NJ, Weedon MN, Zeggini E, Freathy RM, Lindgren $\mathrm{CM}$, et al. A common variant in the FTO gene is associated with body mass index and predisposes to childhood and adult obesity. Science. (2007) 316:889-94. doi: 10.1126/science.1141634

55. Groop L. From fused toes in mice to human obesity. Nat Genet. (2007) 39:706-7. doi: 10.1038/ng0607-706

56. Jacobsson JA, Klovins J, Kapa I, Danielsson P, Svensson V, Ridderstrale M, et al. Novel genetic variant in FTO influences insulin levels and insulin resistance in severely obese children and adolescents. Int J Obesity. (2005) 32:1730-35. doi: 10.1038/ijo.2008.168

57. Al-Attar SA, Pollex RL, Ban MR, Young TK, Bjerregaard P, Anand SS, et al. Association between the FTO rs9939609 polymorphism and the metabolic syndrome in a non-Caucasian multi-ethnic sample. Cardiovasc Diabetol. (2008) 7:5. doi: 10.1186/1475-2840-7-5

58. Wing MR, Ziegler J, Langefeld CD, Ng MC, Haffner SM, Norris JM, et al. Analysis of FTO gene variants with measures of obesity and glucose homeostasis in the IRAS Family Study. Hum Genet. (2009) 125:61526. doi: 10.1007/s00439-009-0656-3

59. Marcadenti A, Fuchs FD, Matte U, Sperb F, Moreira LB, Fuchs SC. Effects of FTO RS9939906 and MC4R RS17782313 on obesity, type 2 diabetes mellitus and blood pressure in patients with hypertension. Cardiovasc Diabetol. (2013) 12:103. doi: 10.1186/1475-2840-12-103

60. Fisher E, Schulze MB, Stefan N, Haring HU, Doring F, Joost HG, et al. Association of the FTO rs9939609 single nucleotide polymorphism with Creactive protein levels. Obesity. (2009) 17:330-4. doi: 10.1038/oby.2008.465

61. Klimentidis YC, Chen GB, Lopez-Alarcon M, Harris JJ, Duarte CW, Fernandez JR. Associations of obesity genes with obesityrelated outcomes in multiethnic children. Arch Med Res. (2011) 42:509-14. doi: 10.1016/j.arcmed.2011.07.003

62. Grunnet LG, Nilsson E, Ling C, Hansen T, Pedersen O, Groop L, et al. Regulation and function of FTO mRNA expression in human skeletal muscle and subcutaneous adipose tissue. Diabetes. (2009) 58:24028. doi: 10.2337/db09-0205

63. Wahlen K, Sjolin E, Hoffstedt J. The common rs9939609 gene variant of the fat mass- and obesity-associated gene FTO is related to fat cell lipolysis. $J$ Lipid Res. (2008) 49:607-11. doi: 10.1194/jlr.M700448-JLR200

64. Smemo S, Tena JJ, Kim KH, Gamazon ER, Sakabe NJ, Gomez-Marin C, et al. Obesity-associated variants within FTO form long-range functional connections with IRX3. Nature. (2014) 507:371-5. doi: 10.1038/nature13138

65. Claussnitzer M, Dankel SN, Kim KH, Quon G, Meuleman W, Haugen C, et al. FTO obesity variant circuitry and adipocyte browning in humans. $N$ Engl J Med. (2015) 373:895-907. doi: 10.1056/NEJMoa1502214

66. Merkestein M, Sellayah D. Role of FTO in adipocyte development and function: recent insights. Int $J$ Endocrinol. (2015) 2015:521381. doi: 10.1155/2015/521381

67. Yang Q, Xiao T, Guo J, Su Z. Complex relationship between obesity and the fat mass and obesity locus. Int J Biol Sci. (2017) 13:61529. doi: 10.7150/ijbs. 17051

68. Fawcett KA, Barroso I. The genetics of obesity: FTO leads the way. Trends Genet. (2010) 26:266-74. doi: 10.1016/j.tig.2010.02.006

69. Fischer J, Koch L, Emmerling C, Vierkotten J, Peters T, Bruning JC, et al. Inactivation of the Fto gene protects from obesity. Nature. (2009) 458:8948. doi: $10.1038 /$ nature 07848

70. Church C, Moir L, McMurray F, Girard C, Banks GT, Teboul L, et al. Overexpression of Fto leads to increased food intake and results in obesity. Nat Genet. (2010) 42:1086-92. doi: 10.1038/ng.713

71. Gerken T, Girard CA, Tung YC, Webby CJ, Saudek V, Hewitson KS, et al. The obesity-associated FTO gene encodes a 2-oxoglutarate-dependent nucleic acid demethylase. Science. (2007) 318:1469-72. doi: 10.1126/science.1151710

72. Ronkainen J, Huusko TJ, Soininen R, Mondini E, Cinti F, Makela $\mathrm{KA}$, et al. Fat mass- and obesity-associated gene Fto affects the 
dietary response in mouse white adipose tissue. Scientific reports. (2015) 5:9233. doi: 10.1038/srep09233

73. Olszewski PK, Fredriksson R, Olszewska AM, Stephansson O, Alsio J, Radomska KJ, et al. Hypothalamic FTO is associated with the regulation of energy intake not feeding reward. BMC Neurosci. (2009) 10:129. doi: 10.1186/1471-2202-10-129

74. Sanchez-Pulido L, Andrade-Navarro MA. The FTO (fat mass and obesity associated) gene codes for a novel member of the non-heme dioxygenase superfamily. BMC Biochem. (2007) 8:23. doi: 10.1186/1471-2091-8-23

75. Wu Q, Saunders RA, Szkudlarek-Mikho M, Serna Ide L, Chin KV. The obesity-associated Fto gene is a transcriptional coactivator. Biochem Biophys Res Commun. (2010) 401:390-5. doi: 10.1016/j.bbrc.2010.09.064

76. Aas PA, Otterlei M, Falnes PO, Vagbo CB, Skorpen F, Akbari M, et al. Human and bacterial oxidative demethylases repair alkylation damage in both RNA and DNA. Nature. (2003) 421:859-63. doi: 10.1038/nature,01363

77. van den Born E, Vagbo CB, Songe-Moller L, Leihne V, Lien GF, Leszczynska G, et al. ALKBH8-mediated formation of a novel diastereomeric pair of wobble nucleosides in mammalian tRNA. Nat Commun. (2011) 2:172. doi: $10.1038 /$ ncomms 1173

78. Jia G, Fu Y, Zhao X, Dai Q, Zheng G, Yang Y, et al. N6-methyladenosine in nuclear RNA is a major substrate of the obesity-associated FTO. Nat Chem Biol. (2011) 7:885-7. doi: 10.1038/nchembio.687

79. Wang X, Zhao BS, Roundtree IA, Lu Z, Han D, Ma H, et al. N(6)methyladenosine Modulates Messenger RNA Translation Efficiency. Cell. (2015) 161:1388-99. doi: 10.1016/j.cell.2015.05.014

80. Sledz P, Jinek M. Structural insights into the molecular mechanism of the m(6)A writer complex. Elife. (2016) 5:e18434. doi: 10.7554/eLife.18434

81. Roignant JY, Soller M. m(6)A in mRNA: an ancient mechanism for fine-tuning gene expression. Trends Genet. (2017) 33:38090. doi: 10.1016/j.tig.2017.04.003

82. Wu R, Jiang D, Wang Y, Wang X. N (6)-Methyladenosine $(\mathrm{m}(6) \mathrm{A})$ Methylation in mRNA with a dynamic and reversible epigenetic modification. Mol Biotechnol. (2016) 58:4509. doi: 10.1007/s12033-016-9947-9

83. Rubio RM, Depledge DP, Bianco C, Thompson L, Mohr I. RNA $\mathrm{m}(6)$ A modification enzymes shape innate responses to DNA by regulating interferon beta. Genes \& development. (2018) 32:1472-84. doi: 10.1101/gad.319475.118

84. Winkler R, Gillis E, Lasman L, Safra M, Geula S, Soyris C, et al. $\mathrm{m}(6) \mathrm{A}$ modification controls the innate immune response to infection by targeting type I interferons. Nat Immunol. (2019) 20:173-82. doi: 10.1038/s41590-018-0275-z

85. Koch L. RNA: The code in the cap. Nat Revi Genetics. (2017) 18:70. doi: 10.1038/nrg.2016.165

86. Sun H, Zhang M, Li K, Bai D, Yi C. Cap-specific, terminal N(6)-methylation by a mammalian m(6)Am methyltransferase. Cell Res. (2019) 29:802. doi: 10.1038/s41422-018-0117-4

87. Deng $\mathrm{X}, \mathrm{Su} \mathrm{R}$, Stanford S, Chen J. Critical enzymatic functions of FTO in obesity and cancer. Front Endocrinol. (2018) 9:396. doi: 10.3389/fendo.2018.00396

88. Yue Y, Liu J, He C. RNA N6-methyladenosine methylation in posttranscriptional gene expression regulation. Genes Dev. (2015) 29:134355. doi: 10.1101/gad.262766.115

89. Zhu T, Roundtree IA, Wang P, Wang X, Wang L, Sun C, et al. Crystal structure of the YTH domain of YTHDF2 reveals mechanism for recognition of N6-methyladenosine. Cell Res. (2014) 24:1493-6. doi: 10.1038/cr.2014.152

90. Li F, Zhao D, Wu J, Shi Y. Structure of the YTH domain of human YTHDF2 in complex with an $\mathrm{m}(6) \mathrm{A}$ mononucleotide reveals an aromatic cage for m(6)A recognition. Cell Res. (2014) 24:1490-2. doi: 10.1038/cr.2014.153

91. Wang X, Lu Z, Gomez A, Hon GC, Yue Y, Han D, et al. N6-methyladenosinedependent regulation of messenger RNA stability. Nature. (2014) 505:11720. doi: 10.1038/nature12730

92. Du H, Zhao Y, He J, Zhang Y, Xi H, Liu M, et al. YTHDF2 destabilizes $\mathrm{m}(6)$ A-containing RNA through direct recruitment of the CCR4-NOT deadenylase complex. Nat Commun. (2016) 7:12626. doi: 10.1038/ ncomms 12626

93. Wu R, Liu Y, Yao Y, Zhao Y, Bi Z, Jiang Q, et al. FTO regulates adipogenesis by controlling cell cycle progression via m(6)A-YTHDF2 dependent mechanism. Biochim Biophys Acta Mol Cell Biol Lipids. (2018) 1863:1323-30. doi: 10.1016/j.bbalip.2018.08.008

94. Yu R, Li Q, Feng Z, Cai L, Xu Q. m6A Reader YTHDF2 Regulates LPS-induced inflammatory response. Int J Mol Sci. (2019) 20:1-12. doi: 10.3390/ijms20061323

95. Meyer KD, Saletore Y, Zumbo P, Elemento O, Mason CE, Jaffrey SR. Comprehensive analysis of mRNA methylation reveals enrichment in 3' UTRs and near stop codons. Cell. (2012) 149:1635-46. doi: 10.1016/j.cell.2012.05.003

96. Dominissini D, Moshitch-Moshkovitz S, Schwartz S, Salmon-Divon M, Ungar L, Osenberg S, et al. Topology of the human and mouse m6A RNA methylomes revealed by m6A-seq. Nature. (2012) 485:2016. doi: $10.1038 /$ nature 11112

97. Grozhik AV, Jaffrey SR. Distinguishing RNA modifications from noise in epitranscriptome maps. Nat Chem Biol. (2018) 14:215-25. doi: $10.1038 /$ nchembio. 2546

98. Schwartz S. Cracking the epitranscriptome. RNA. (2016) 22:169-74. doi: 10.1261/rna.054502.115

99. Molinie B, Wang J, Lim KS, Hillebrand R, Lu ZX, Van Wittenberghe N, et al. m(6)A-LAIC-seq reveals the census and complexity of the m(6)A epitranscriptome. Nat Methods. (2016) 13:692-8. doi: 10.1038/nmeth.3898

100. Schwartz S, Agarwala SD, Mumbach MR, Jovanovic M, Mertins P, Shishkin A, et al. High-resolution mapping reveals a conserved, widespread, dynamic mRNA methylation program in yeast meiosis. Cell. (2013) 155:140921. doi: 10.1016/j.cell.2013.10.047

101. Schwartz S, Bernstein DA, Mumbach MR, Jovanovic M, Herbst RH, Leon-Ricardo BX, et al. Transcriptome-wide mapping reveals widespread dynamic-regulated pseudouridylation of ncRNA and mRNA. Cell. (2014) 159:148-62. doi: 10.1016/j.cell.2014.08.028

102. Linder B, Grozhik AV, Olarerin-George AO, Meydan C, Mason CE, Jaffrey SR. Single-nucleotide-resolution mapping of m6A and m6Am throughout the transcriptome. Nature methods. (2015) 12:767-72. doi: $10.1038 /$ nmeth. 3453

103. Garcia-Campos MA, Edelheit S, Toth U, Safra M, Shachar R, Viukov S, et al. Deciphering the "m(6)A Code" via antibody-independent quantitative profiling. Cell. (2019) 178:1-17. doi: 10.1016/j.cell.2019.06.013.

104. Imanishi M, Tsuji S, Suda A, Futaki S. Detection of N(6)-methyladenosine based on the methyl-sensitivity of MazF RNA endonuclease. Chem Commun. (2017) 53:12930-3. doi: 10.1039/C7CC07699A

105. Motorin Y, Marchand V. Detection and analysis of RNA Ribose 2'-O-methylations: challenges and solutions. Genes. (2018) 9:1-14. doi: 10.3390/genes9120642

106. Ayadi L, Galvanin A, Pichot F, Marchand V, Motorin Y. RNA ribose methylation (2'-O-methylation): Occurrence, biosynthesis and biological functions. Biochim Biophys Acta Gene Regul Mechan. (2019) 1862:25369. doi: 10.1016/j.bbagrm.2018.11.009

107. Gehrig S, Eberle ME, Botschen F, Rimbach K, Eberle F, Eigenbrod $\mathrm{T}$, et al. Identification of modifications in microbial, native tRNA that suppress immunostimulatory activity. J Exp Med. (2012) 209:22533. doi: 10.1084/jem.20111044

108. Dalpke A, Helm M. RNA mediated Toll-like receptor stimulation in health and disease. RNA Biol. (2012) 9:828-42. doi: 10.4161/rna.20206

109. Jockel S, Nees G, Sommer R, Zhao Y, Cherkasov D, Hori H, et al. The 2'O-methylation status of a single guanosine controls transfer RNA-mediated Toll-like receptor 7 activation or inhibition. J Exp Med. (2012) 209:23541. doi: 10.1084/jem.20111075

110. Rimbach K, Kaiser S, Helm M, Dalpke AH, Eigenbrod T. 2'-OMethylation within Bacterial RNA Acts as Suppressor of TLR7/TLR8 Activation in Human Innate Immune Cells. Innate Immun.(2015) 7:48293. doi: 10.1159/000375460

111. Li K, Li NL, Wei D, Pfeffer SR, Fan M, Pfeffer LM. Activation of chemokine and inflammatory cytokine response in hepatitis $\mathrm{C}$ virusinfected hepatocytes depends on Toll-like receptor 3 sensing of hepatitis C virus double-stranded RNA intermediates. Hepatology. (2012) 55:666-75. doi: 10.1002/hep.24763

112. Revelo XS, Ghazarian M, Chng MH, Luck H, Kim JH, Zeng K, et al. Nucleic acid-targeting pathways promote inflammation in obesity-related insulin resistance. Cell Rep. (2016) 16:717-30. doi: 10.1016/j.celrep.2016.06.024 
113. Liu CL, Santos MM, Fernandes C, Liao M, Iamarene K, Zhang JY, et al. Toll-like receptor 7 deficiency protects apolipoprotein Edeficient mice from diet-induced atherosclerosis. Sci Rep. (2017) 7:847. doi: 10.1038/s41598-017-00977-0

114. Salagianni M, Galani IE, Lundberg AM, Davos $\mathrm{CH}$, Varela A, Gavriil A, et al. Toll-like receptor 7 protects from atherosclerosis by constraining "inflammatory" macrophage activation. Circulation. (2012) 126:952-62. doi: 10.1161/CIRCULATIONAHA.111.067678

115. Edfeldt K, Swedenborg J, Hansson GK, Yan ZQ. Expression of toll-like receptors in human atherosclerotic lesions: a possible pathway for plaque activation. Circulation. (2002) 105:1158-61. doi: 10.1161/circ.105.10.1158

116. Karadimou G, Folkersen L, Berg M, Perisic L, Discacciati A, Roy J, et al. Low TLR7 gene expression in atherosclerotic plaques is associated with major adverse cardio- and cerebrovascular events. Cardiovasc Res. (2017) 113:30-9. doi: 10.1093/cvr/cvw231

117. Schmitt FCF, Freund I, Weigand MA, Helm M, Dalpke AH, Eigenbrod T. Identification of an optimized 2'-O-methylated trinucleotide RNA motif inhibiting Toll-like receptors 7 and 8. RNA. (2017) 23:134451. doi: 10.1261/rna.061952.117

118. Kufel J, Grzechnik P. Small nucleolar RNAs tell a different tale. Trends Genet. (2019) 35:104-17. doi: 10.1016/j.tig.2018.11.005

119. McMahon M, Contreras A, Ruggero D. Small RNAs with big implications: new insights into H/ACA snoRNA function and their role in human disease. Wiley Interdisc Rev RNA. (2015) 6:173-89. doi: 10.1002/wrna.1266

120. Falaleeva M, Welden JR, Duncan MJ, Stamm S. C/D-box snoRNAs form methylating and non-methylating ribonucleoprotein complexes: Old dogs show new tricks. Bioessays. (2017) 39. doi: 10.1002/bies.201600264

121. Ender C, Krek A, Friedlander MR, Beitzinger M, Weinmann L, Chen W, et al. A human snoRNA with microRNA-like functions. Mol Cell. (2008) 32:519-28. doi: 10.1016/j.molcel.2008.10.017

122. Pages A, Dotu I, Pallares-Albanell J, Marti E, Guigo R, Eyras E. The discovery potential of RNA processing profiles. Nucleic Acids Res. (2018) 46:e15. doi: 10.1093/nar/gkx1115

123. Falaleeva M, Pages A, Matuszek Z, Hidmi S, Agranat-Tamir L, Korotkov $\mathrm{K}$, et al. Dual function of $\mathrm{C} / \mathrm{D}$ box small nucleolar RNAs in rRNA modification and alternative pre-mRNA splicing. Proc Natl Acad Sci USA. (2016) 113:E1625-34. doi: 10.1073/pnas.1519292113

124. Lee J, Harris AN, Holley CL, Mahadevan J, Pyles KD, Lavagnino Z, et al. Rpl13a small nucleolar RNAs regulate systemic glucose metabolism. J Clin Investig. (2016) 126:4616-25. doi: 10.1172/JCI88069

125. Brandis KA, Gale S, Jinn S, Langmade SJ, Dudley-Rucker N, Jiang $\mathrm{H}$, et al. Box C/D small nucleolar RNA (snoRNA) U60 regulates intracellular cholesterol trafficking. J Biol Chem. (2013) 288:3570313. doi: 10.1074/jbc.M113.488577

126. Rimer JM, Lee J, Holley CL, Crowder RJ, Chen DL, Hanson $\mathrm{PI}$, et al. Long-range function of secreted small nucleolar RNAs that direct 2'-O-methylation. J Biol Chem. (2018) 293:1328496. doi: 10.1074/jbc.RA118.003410

127. Bieth E, Eddiry S, Gaston V, Lorenzini F, Buffet A, Conte Auriol $\mathrm{F}$, et al. Highly restricted deletion of the SNORD116 region is implicated in Prader-Willi Syndrome. Eur J Hum Genet. (2015) 23:252-5. doi: 10.1038/ejhg.2014.103

128. Polex-Wolf J, Lam BY, Larder R, Tadross J, Rimmington D, Bosch F, et al. Hypothalamic loss of Snord116 recapitulates the hyperphagia of Prader-Willi syndrome. J Clin Investig. (2018) 128:960-9. doi: 10.1172/JCI97007

129. Diebold SS, Kaisho T, Hemmi H, Akira S, Reis e Sousa C. Innate antiviral responses by means of TLR7-mediated recognition of single-stranded RNA. Science. (2004) 303:1529-31. doi: 10.1126/science.1093616

130. Heil F, Hemmi H, Hochrein H, Ampenberger F, Kirschning C, Akira S, et al. Species-specific recognition of single-stranded RNA via toll-like receptor 7 and 8. Science. (2004) 303:1526-9. doi: 10.1126/science.1093620

131. Jin C, Henao-Mejia J, Flavell RA. Innate immune receptors: key regulators of metabolic disease progression. Cell Metab. (2013) 17:87382. doi: 10.1016/j.cmet.2013.05.011

132. Taylor SS, Haste NM, Ghosh G. PKR and eIF2alpha: integration of kinase dimerization, activation, and substrate docking. Cell. (2005) 122:8235. doi: 10.1016/j.cell.2005.09.007
133. Donnelly N, Gorman AM, Gupta S, Samali A. The eIF2alpha kinases: their structures and functions. Cell Mol Life Sci. (2013) 70:3493511. doi: 10.1007/s00018-012-1252-6

134. Holcik M, Sonenberg N. Translational control in stress and apoptosis. Nat Rev Mol Cell Biol. (2005) 6:318-27. doi: 10.1038/nrm1618

135. Gal-Ben-Ari S, Barrera I, Ehrlich M, Rosenblum K. PKR: A Kinase to Remember. Front Mol Neurosci. (2018) 11:480. doi: 10.3389/fnmol.2018.00480

136. Hotamisligil GS. Endoplasmic reticulum stress and the inflammatory basis of metabolic disease. Cell. (2010) 140:900-17. doi: 10.1016/j.cell.2010. 02.034

137. Carvalho BM, Oliveira AG, Ueno M, Araujo TG, Guadagnini D, CarvalhoFilho MA, et al. Modulation of double-stranded RNA-activated protein kinase in insulin sensitive tissues of obese humans. Obesity. (2013) 21:24527. doi: 10.1002/oby.20410

138. Youssef OA, Safran SA, Nakamura T, Nix DA, Hotamisligil GS, Bass BL. Potential role for snoRNAs in PKR activation during metabolic stress. Proc Natl Acad Sci USA. (2015) 112:5023-8. doi: 10.1073/pnas.1424044112

139. Bachellerie JP, Cavaille J, Huttenhofer A. The expanding snoRNA world. Biochimie. (2002) 84:775-90. doi: 10.1016/S0300-9084(02)01402-5

140. Kim Y, Lee JH, Park JE, Cho J, Yi H, Kim VN. PKR is activated by cellular dsRNAs during mitosis and acts as a mitotic regulator. Genes Dev. (2014) 28:1310-22. doi: 10.1101/gad.242644.114

141. Kim Y, Park J, Kim S, Kim M, Kang MG, Kwak C, et al. PKR Senses Nuclear and Mitochondrial Signals by Interacting with Endogenous Double-Stranded RNAs. Mol Cell. (2018) 71:1051-1063.e6. doi: 10.1016/j.molcel.2018.07.029

142. Pindel A, Sadler A. The role of protein kinase $\mathrm{R}$ in the interferon response. $J$ Interferon Cytokine Res. (2011) 31:59-70. doi: 10.1089/jir.2010.0099

143. Cohen-Chalamish S, Hasson A, Weinberg D, Namer LS, Banai Y, Osman F, et al. Dynamic refolding of IFN-gamma mRNA enables it to function as PKR activator and translation template. Nat Chem Biol. (2009) 5:896903. doi: 10.1038/nchembio.234

144. Namer LS, Osman F, Banai Y, Masquida B, Jung R, Kaempfer R. An ancient pseudoknot in TNF-alpha Pre-mRNA activates PKR, inducing eIF2alpha phosphorylation that potently enhances splicing. Cell Rep. (2017) 20:188200. doi: 10.1016/j.celrep.2017.06.035

145. Kaempfer R, Ilan L, Cohen-Chalamish S, Turgeman O, Namer LS, Osman F. Control of mRNA splicing by intragenic RNA activators of stress signaling: potential implications for human disease. Front Genet. (2019) 10:464. doi: 10.3389/fgene.2019.00464

146. Carvalho-Filho MA, Carvalho BM, Oliveira AG, Guadagnini D, Ueno M, Dias MM, et al. Double-stranded RNA-activated protein kinase is a key modulator of insulin sensitivity in physiological conditions and in obesity in mice. Endocrinology. (2012) 153:5261-74. doi: 10.1210/en.2012-1400

147. Nakamura T, Kunz RC, Zhang C, Kimura T, Yuan CL, Baccaro B, et al. A critical role for PKR complexes with TRBP in Immunometabolic regulation and eIF2alpha phosphorylation in obesity. Cell Rep. (2015) 11:295-307. doi: 10.1016/j.celrep.2015.03.021

148. Lancaster GI, Kammoun HL, Kraakman MJ, Kowalski GM, Bruce CR, Febbraio MA. PKR is not obligatory for high-fat diet-induced obesity and its associated metabolic and inflammatory complications. Nat Commun. (2016) 7:10626. doi: 10.1038/ncomms10626

149. Taga M, Mouton-Liger F, Sadoune M, Gourmaud S, Norman J, Tible M, et al. PKR modulates abnormal brain signaling in experimental obesity. PLoS ONE. (2018) 13:e0196983. doi: 10.1371/journal.pone.0196983

150. Abraham N, Stojdl DF, Duncan PI, Methot N, Ishii T, Dube M, et al. Characterization of transgenic mice with targeted disruption of the catalytic domain of the double-stranded RNA-dependent protein kinase, PKR. J Biol Chem. (1999) 274:5953-62. doi: 10.1074/jbc.274.9.5953

151. Baltzis D, Li S, Koromilas AE. Functional characterization of pkr gene products expressed in cells from mice with a targeted deletion of the $\mathrm{N}$ terminus or C terminus domain of PKR. J Biol Chem. (2002) 277:3836472. doi: 10.1074/jbc.M203564200

152. Yang YL, Reis LF, Pavlovic J, Aguzzi A, Schafer R, Kumar A, et al. Deficient signaling in mice devoid of double-stranded RNA-dependent protein kinase. EMBO J. (1995) 14:6095-106. doi: 10.1002/j.1460-2075.1995.tb00300.x 
153. Cao SS, Song B, Kaufman RJ. PKR protects colonic epithelium against colitis through the unfolded protein response and prosurvival signaling. Inflammatory Bowel Dis. (2012) 18:1735-42. doi: 10.1002/ibd. 22878

154. Rath E, Berger E, Messlik A, Nunes T, Liu B, Kim SC, et al. Induction of dsRNA-activated protein kinase links mitochondrial unfolded protein response to the pathogenesis of intestinal inflammation. Gut. (2012) 61:1269-78. doi: 10.1136/gutjnl-2011-300767

155. Carvalho BM, Saad MJ. Influence of gut microbiota on subclinical inflammation and insulin resistance. Med Inflammation. (2013) 2013:986734. doi: 10.1155/2013/986734

156. Nakamura T, Arduini A, Baccaro B, Furuhashi M, Hotamisligil GS. Smallmolecule inhibitors of PKR improve glucose homeostasis in obese diabetic mice. Diabetes. (2014) 63:526-34. doi: 10.2337/db13-1019

157. Valentine RJ, Jefferson MA, Kohut ML, Eo H. Imoxin attenuates LPSinduced inflammation and MuRF1 expression in mouse skeletal muscle. Physiol Rep. (2018) 6:e13941. doi: 10.14814/phy2.13941

158. Udumula MP, Bhat A, Mangali S, Kalra J, Dhar I, Sriram D, et al. Pharmacological evaluation of novel PKR inhibitor indirubin-3-hydrazone in-vitro in cardiac myocytes and in-vivo in wistar rats. Life Sci. (2018) 209:85-96. doi: 10.1016/j.lfs.2018.07.055

159. Farabaugh KT, Majumder M, Guan BJ, Jobava R, Wu J, Krokowski $\mathrm{D}$, et al. Protein kinase $\mathrm{R}$ mediates the inflammatory response induced by hyperosmotic stress. Mol Cell Biol. (2017) 37:1-22. doi: 10.1128/MCB.00521-16

160. Hwang KD, Bak MS, Kim SJ, Rhee S, Lee YS. Restoring synaptic plasticity and memory in mouse models of Alzheimer's disease by PKR inhibition. Mol Brain. (2017) 10:57. doi: 10.1186/s13041-017-0338-3

161. Maillard PV, Ciaudo C, Marchais A, Li Y, Jay F, Ding SW, et al. Antiviral RNA interference in mammalian cells. Science. (2013) 342:2358. doi: $10.1126 /$ science. 1241930

162. Li Y, Lu J, Han Y, Fan X, Ding SW. RNA interference functions as an antiviral immunity mechanism in mammals. Science. (2013) 342:2314. doi: 10.1126/science.1241911

163. Arner P, Kulyte A. MicroRNA regulatory networks in human adipose tissue and obesity. Nat Rev Endocrinol. (2015) 11:27688. doi: $10.1038 /$ nrendo. 2015.25

164. Ross SA, Davis CD. The emerging role of microRNAs and nutrition in modulating health and disease. Annu Rev Nutr. (2014) 34:30536. doi: 10.1146/annurev-nutr-071813-105729

165. Chendrimada TP, Gregory RI, Kumaraswamy E, Norman J, Cooch $\mathrm{N}$, Nishikura $\mathrm{K}$, et al. TRBP recruits the Dicer complex to Ago2 for microRNA processing and gene silencing. Nature. (2005) 436:7404. doi: 10.1038/nature03868

166. Redfern AD, Colley SM, Beveridge DJ, Ikeda N, Epis MR, Li X, et al. RNAinduced silencing complex (RISC) Proteins PACT, TRBP, and Dicer are SRA binding nuclear receptor coregulators. Proc Natl Acad Sci USA. (2013) 110:6536-41. doi: 10.1073/pnas.1301620110

167. Paroo Z, Ye X, Chen S, Liu Q. Phosphorylation of the human microRNAgenerating complex mediates MAPK/Erk signaling. Cell. (2009) 139:11222. doi: 10.1016/j.cell.2009.06.044

168. Chukwurah E, Patel RC. Stress-induced TRBP phosphorylation enhances its interaction with PKR to regulate cellular survival. Sci Rep. (2018) 8:1020. doi: 10.1038/s41598-018-19360-8

169. Daniels SM, Gatignol A. The multiple functions of TRBP, at the hub of cell responses to viruses, stress, and cancer. Microbiol Mol Biol Rev. (2012) 76:652-66. doi: 10.1128/MMBR.00012-12

170. Rottiers V, Naar AM. MicroRNAs in metabolism and metabolic disorders. Nat Rev Mol Cell Biol. (2012) 13:239-50. doi: 10.1038/nrm3313

171. Kornfeld JW, Baitzel C, Konner AC, Nicholls HT, Vogt MC, Herrmanns K, et al. Obesity-induced overexpression of miR-802 impairs glucose metabolism through silencing of Hnf1b. Nature. (2013) 494:111-5. doi: 10.1038/nature11793

172. Soronen J, Yki-Jarvinen H, Zhou Y, Sadevirta S, Sarin AP, Leivonen M, et al. Novel hepatic microRNAs upregulated in human nonalcoholic fatty liver disease. Physiol Rep. (2016) 4:1-14. doi: 10.14814/phy2.12661

173. Sekine S, Ogawa R, Ito R, Hiraoka N, McManus MT, Kanai Y, et al. Disruption of Dicer1 induces dysregulated fetal gene expression and promotes hepatocarcinogenesis. Gastroenterology. (2009) 136, 23042315.e1-4. doi: 10.1053/j.gastro.2009.02.067

174. Lu XF, Zhou YJ, Zhang L, Ji HJ, Li L, Shi YJ, et al. Loss of Dicer1 impairs hepatocyte survival and leads to chronic inflammation and progenitor cell activation. World J Gastroenterol. (2015) 21:6591603. doi: 10.3748/wjg.v21.i21.6591

175. Valdmanis PN, Gu S, Schuermann N, Sethupathy P, Grimm D, Kay MA. Expression determinants of mammalian argonaute proteins in mediating gene silencing. Nucleic Acids Res. (2012) 40:3704-13. doi: 10.1093/nar/gkr1274

176. Trajkovski M, Hausser J, Soutschek J, Bhat B, Akin A, Zavolan M, et al. MicroRNAs 103 and 107 regulate insulin sensitivity. Nature. (2011) 474:64953. doi: 10.1038/nature10112

177. Wagschal A, Najafi-Shoushtari SH, Wang L, Goedeke L, Sinha S, deLemos AS, et al. (2015). Genome-wide identification of microRNAs regulating cholesterol and triglyceride homeostasis. Nat Med. 21, 12901297. doi: $10.1038 / \mathrm{nm} .3980$

178. Goedeke L, Rotllan N, Canfran-Duque A, Aranda JF, Ramirez CM, Araldi E, et al. MicroRNA-148a regulates LDL receptor and ABCA1 expression to control circulating lipoprotein levels. Nat Med. (2015) 21:12809. doi: 10.1038/nm.3949

179. Yan X, Wang Z, Bishop CA, Weitkunat K, Feng X, Tarbier M, et al. Control of hepatic gluconeogenesis by Argonaute2. Mol Metab. (2018) 18:15-24. doi: 10.1016/j.molmet.2018.10.003

180. Roundtree IA, Evans ME, Pan T, He C. Dynamic RNA Modifications in Gene Expression Regulation. Cell. (2017) 169:1187-200. doi: 10.1016/j.cell.2017.05.045

181. Ke S, Alemu EA, Mertens C, Gantman EC, Fak JJ, Mele A, et al. A majority of $\mathrm{m} 6 \mathrm{~A}$ residues are in the last exons, allowing the potential for 3' UTR regulation. Genes Dev. (2015) 29:2037-53. doi: 10.1101/gad.269415.115

182. Squires JE, Patel HR, Nousch M, Sibbritt T, Humphreys DT, Parker BJ, et al. Widespread occurrence of 5-methylcytosine in human coding and noncoding RNA. Nucleic Acids Res. (2012) 40:5023-33. doi: 10.1093/nar/gks144

183. Ogorodnikov A, Kargapolova Y, Danckwardt S. Processing and transcriptome expansion at the mRNA 3' end in health and disease: finding the right end. Pflugers Arch. (2016) 468:993-1012. doi: 10.1007/s00424-016-1828-3

184. Chen CY, Shyu AB. Mechanisms of deadenylation-dependent decay. Wiley Interdisc Rev RNA. (2011) 2:167-83. doi: 10.1002/wrna.40

185. Shirai YT, Suzuki T, Morita M, Takahashi A, Yamamoto T. Multifunctional roles of the mammalian CCR4-NOT complex in physiological phenomena. Front Genet. (2014) 5:286. doi: 10.3389/fgene.2014.00286

186. Albert TK, Lemaire $M$, van Berkum NL, Gentz R, Collart MA, Timmers HT. Isolation and characterization of human orthologs of yeast CCR4-NOT complex subunits. Nucleic Acids Res. (2000) 28:80917. doi: 10.1093/nar/28.3.809

187. Collart MA, Timmers HT. The eukaryotic Ccr4-not complex: a regulatory platform integrating mRNA metabolism with cellular signaling pathways? Prog Nucleic Acid Res Mol Biol. (2004) 77:289-322. doi: 10.1016/S0079-6603(04)77008-7

188. Inada $\mathrm{T}$, Makino $\mathrm{S}$. Novel roles of the multi-functional CCR4NOT complex in post-transcriptional regulation. Front Genet. (2014) 5:135. doi: 10.3389/fgene.2014.00135

189. Chapat C, Jafarnejad SM, Matta-Camacho E, Hesketh GG, Gelbart IA, Attig J, et al. Cap-binding protein 4EHP effects translation silencing by microRNAs. Proc Natl Acad Sci USA. (2017) 114:5425-30. doi: 10.1073/pnas.1701488114

190. Morita M, Oike Y, Nagashima T, Kadomatsu T, Tabata M, Suzuki $\mathrm{T}$, et al. Obesity resistance and increased hepatic expression of catabolism-related mRNAs in Cnot $3+/$ - mice. Embo J. (2011) 30:4678-91. doi: 10.1038/emboj.2011.320

191. Suzuki T, Kikuguchi C, Nishijima S, Nagashima T, Takahashi A, Okada M, et al. Postnatal liver functional maturation requires Cnot complex-mediated decay of mRNAs encoding cell cycle and immature liver genes. Development. (2019) 146:1-15. doi: 10.1242/dev.168146

192. Morita M, Siddiqui N, Katsumura S, Rouya C, Larsson O, Nagashima T, et al. Hepatic posttranscriptional network comprised of CCR4-NOT deadenylase and FGF21 maintains systemic metabolic homeostasis. Proc Natl Acad Sci USA. (2019) 116:7973-81. doi: 10.1073/pnas.1816023116 
193. Li X, Morita M, Kikuguchi C, Takahashi A, Suzuki T, Yamamoto T. Adipocyte-specific disruption of mouse Cnot3 causes lipodystrophy. FEBS Lett. (2017) 591:358-68. doi: 10.1002/1873-3468.12550

194. Takahashi A, Adachi S, Morita M, Tokumasu M, Natsume T, Suzuki T, et al. Post-transcriptional stabilization of Ucp1 mRNA protects mice from diet-induced obesity. Cell Rep. (2015) 13:2756-67. doi: 10.1016/j.celrep.2015.11.056

195. Ezzeddine N, Chen CY, Shyu AB. Evidence providing new insights into TOB-promoted deadenylation and supporting a link between TOB's deadenylation-enhancing and antiproliferative activities. Mol Cell Biol. (2012) 32:1089-98. doi: 10.1128/MCB.06370-11

196. Ogami K, Hosoda N, Funakoshi Y, Hoshino S. Antiproliferative protein Tob directly regulates c-myc proto-oncogene expression through cytoplasmic polyadenylation element-binding protein CPEB. Oncogene. (2014) 33:5564. doi: 10.1038/onc.2012.548

197. Horiuchi M, Takeuchi K, Noda N, Muroya N, Suzuki T, Nakamura T, et al. Structural basis for the antiproliferative activity of the Tob-hCafl complex. $J$ Biol Chem. (2009) 284:13244-55. doi: 10.1074/jbc.M809250200

198. Takahashi A, Morita M, Yokoyama K, Suzuki T, Yamamoto T. Tob2 inhibits peroxisome proliferator-activated receptor gamma2 expression by sequestering Smads and C/EBPalpha during adipocyte differentiation. Mol Cell Biol. (2012) 32:5067-77. doi: 10.1128/MCB.00610-12

199. Kalra J, Mangali SB, Bhat A, Dhar I, Udumula MP, Dhar A. Imoxin attenuates high fructose-induced oxidative stress and apoptosis in renal epithelial cells via downregulation of protein kinase $\mathrm{R}$ pathway. Fundamental Clin Pharmacol. (2018) 32:297-305. doi: 10.1111/fcp.12352

200. Hu Y, Conway TW. 2-Aminopurine inhibits the double-stranded RNAdependent protein kinase both in vitro and in vivo. J Interferon Res. (1993) 13:323-8. doi: 10.1089/jir.1993.13.323

201. Obad S, dos Santos CO, Petri A, Heidenblad M, Broom O, Ruse C, et al. Silencing of microRNA families by seed-targeting tiny LNAs. Nat Genetics. (2011) 43:371-8. doi: 10.1038/ng.786

202. Schmidt MF, Korb O, Abell C. MicroRNA-specific argonaute 2 protein inhibitors. ACS Chem Biol. (2013) 8:2122-6. doi: 10.1021/cb400246k

203. Matsuyama Y, Yamayoshi A, Kobori A, Murakami A. Functional regulation of RNA-induced silencing complex by photoreactive oligonucleotides. Bioorganic Med Chem. (2014) 22:1003-7. doi: 10.1016/j.bmc.2013.12.044

204. Tan GS, Chiu CH, Garchow BG, Metzler D, Diamond SL, Kiriakidou M. Small molecule inhibition of RISC loading. ACS Chem Biol. (2012) 7:40310. doi: 10.1021/cb200253h

205. Masciarelli S, Quaranta R, Iosue I, Colotti G, Padula F, Varchi G, et al. A small-molecule targeting the microRNA binding domain of argonaute 2 improves the retinoic acid differentiation response of the acute promyelocytic leukemia cell line NB4. ACS Chem Biol. (2014) 9:16749. doi: 10.1021/cb500286b

206. Trang P, Wiggins JF, Daige CL, Cho C, Omotola M, Brown D, et al. Systemic delivery of tumor suppressor microRNA mimics using a neutral lipid emulsion inhibits lung tumors in mice. Mol Ther J Am Soc Gene Ther. (2011) 19:1116-22. doi: 10.1038/mt.2011.48

207. Lennox KA, Behlke MA. A direct comparison of anti-microRNA oligonucleotide potency. Pharmaceutical Res. (2010) 27:178899. doi: 10.1007/s11095-010-0156-0

208. Krutzfeldt J, Rajewsky N, Braich R, Rajeev KG, Tuschl T, Manoharan M, et al. Silencing of microRNAs in vivo with 'antagomirs'. Nature. (2005) 438:685-9. doi: 10.1038/nature04303

209. Jopling CL, Yi M, Lancaster AM, Lemon SM, Sarnow P. Modulation of hepatitis C virus RNA abundance by a liver-specific MicroRNA. Science. (2005) 309:1577-81. doi: 10.1126/science.1113329
210. Lanford RE, Hildebrandt-Eriksen ES, Petri A, Persson R, Lindow M, Munk ME, et al. Therapeutic silencing of microRNA-122 in primates with chronic hepatitis C virus infection. Science. (2010) 327:198201. doi: $10.1126 /$ science. 1178178

211. Janssen HL, Reesink HW, Lawitz EJ, Zeuzem S, Rodriguez-Torres M, Patel $\mathrm{K}$, et al. Treatment of HCV infection by targeting microRNA. N Engl J Med. (2013) 368:1685-94. doi: 10.1056/NEJMoa1209026

212. van der Ree MH, de Vree JM, Stelma F, Willemse S, van der Valk M, Rietdijk S, et al. Safety, tolerability, and antiviral effect of RG-101 in patients with chronic hepatitis $\mathrm{C}$ : a phase $1 \mathrm{~B}$, double-blind, randomised controlled trial. Lancet. (2017) 389:709-17. doi: 10.1016/S0140-6736(16) 31715-9

213. Zhu H, Shyh-Chang N, Segre AV, Shinoda G, Shah SP, Einhorn WS, et al. The Lin28/let-7 axis regulates glucose metabolism. Cell. (2011) 147:8194. doi: 10.1016/j.cell.2011.08.033

214. Dai N, Zhao L, Wrighting D, Kramer D, Majithia A, Wang Y, et al. IGF2BP2/IMP2-Deficient mice resist obesity through enhanced translation of Ucp1 mRNA and Other mRNAs encoding mitochondrial proteins. Cell Metab. (2015) 21:609-21. doi: 10.1016/j.cmet.2015.03.006

215. Li J, Gong L, Liu S, Zhang Y, Zhang C, Tian M, et al. Adipose HuR protects against diet-induced obesity and insulin resistance. Nat Commun. (2019) 10:2375. doi: 10.1038/s41467-019-10348-0

216. Niu Y, Zhao X, Wu YS, Li MM, Wang XJ, Yang YG. N6methyl-adenosine (m6A) in RNA: an old modification with a novel epigenetic function. Genomics Proteomics Bioinform. (2013) 11:8-17. doi: 10.1016/j.gpb.2012.12.002

217. Jia G, Fu Y, He C. Reversible RNA adenosine methylation in biological regulation. Trends Genet. (2013) 29:108-15. doi: 10.1016/j.tig.2012.11.003

218. Jonkhout N, Tran J, Smith MA, Schonrock N, Mattick JS, Novoa EM. The RNA modification landscape in human disease. RNA. (2017) 23:175469. doi: 10.1261/rna.063503.117

219. Hrdlickova R, Toloue M, Tian B. RNA-Seq methods for transcriptome analysis. Wiley Interdisc Rev RNA. (2017) 8:1364. doi: 10.1002/wrna.1364

220. Ovcharenko A, Rentmeister A. Emerging approaches for detection of methylation sites in RNA. Open Biol. (2018) 8:180121. doi: 10.1098/rsob.180121

221. Wheeler EC, Van Nostrand EL, Yeo GW. Advances and challenges in the detection of transcriptome-wide protein-RNA interactions. Wiley Interdisc Rev RNA. (2018) 9:1436. doi: 10.1002/ wrna. 1436

222. Hawley BR, Jaffrey SR. Transcriptome-Wide Mapping of $m(6)$ A and $m(6)$ am at single-nucleotide resolution using miCLIP. Curr Protoc Mol Biol. (2019) 126:e88. doi: 10.1002/cpmb.88

223. Ule J, Hwang H-W, Darnell RB. The future of cross-linking and immunoprecipitation (CLIP). Cold Spring Harb Perspect Biol. (2018) 10:a032243. doi: 10.1101/cshperspect.a032243

Conflict of Interest Statement: The authors declare that the research was conducted in the absence of any commercial or financial relationships that could be construed as a potential conflict of interest.

Copyright (c) 2019 Salem, Vonberg, Borra, Gill and Nakamura. This is an open-access article distributed under the terms of the Creative Commons Attribution License (CC $B Y)$. The use, distribution or reproduction in other forums is permitted, provided the original author(s) and the copyright owner(s) are credited and that the original publication in this journal is cited, in accordance with accepted academic practice. No use, distribution or reproduction is permitted which does not comply with these terms. 